\title{
Nucleic Acid Vaccines for COVID-19: A Paradigm Shift in the Vaccine Development Arena
}

\author{
Vivek P. Chavda ${ }^{1, *}$, Md Kamal Hossain ${ }^{2}$, Jayesh Beladiya ${ }^{3}$ and Vasso Apostolopoulos ${ }^{2,4}$ (D) \\ 1 Department of Pharmaceutics and Pharmaceutical Technology, L M College of Pharmacy, \\ Ahmedabad 380009, Gujarat, India \\ 2 Institute for Health and Sport, Victoria University, Melbourne, VIC 3030, Australia; \\ md.hossain18@live.vu.edu.au (M.K.H.); vasso.apostolopoulos@vu.edu.au (V.A.) \\ 3 Department of Pharmacology, L M College of Pharmacy, Ahmedabad 380009, Gujarat, India; \\ jayesh.beladiya@lmcp.ac.in \\ 4 Immunology Program, Australian Institute for Musculoskeletal Science, Melbourne, VIC 3021, Australia \\ * Correspondence: vivek.chavda@lmcp.ac.in or vivek7chavda@gmail.com
}

check for updates

Citation: Chavda, V.P.; Hossain, M.K.; Beladiya, J.; Apostolopoulos, V. Nucleic Acid Vaccines for COVID-19: A Paradigm Shift in the Vaccine Development Arena. Biologics 2021, 1 , 337-356. https://doi.org/10.3390/ biologics1030020

Academic Editors: Alexander Zakhartchouk, Gary McLean and Raffaele Capasso

Received: 29 June 2021

Accepted: 20 October 2021

Published: 23 October 2021

Publisher's Note: MDPI stays neutral with regard to jurisdictional claims in published maps and institutional affiliations.

Copyright: (c) 2021 by the authors. Licensee MDPI, Basel, Switzerland. This article is an open access article distributed under the terms and conditions of the Creative Commons Attribution (CC BY) license (https:// creativecommons.org/licenses/by/ $4.0 /)$.

\begin{abstract}
Coronavirus disease, COVID-19, has touched every country globally except five countries (North Korea, Turkmenistan, Tonga, Tuvalu and Nauru). Vaccination is the most effective method to protect against infectious diseases. The objective is to ensure that everyone has access to a COVID-19 vaccine. The conventional vaccine development platforms are complex and time-consuming to obtain desired approved vaccine candidates through rigorous regulatory pathways. These safeguards guarantee that the optimized vaccine product is safe and efficacious for various demographic populations prior to it being approved for general use. Nucleic acid vaccines employ genetic material from a pathogen, such as a virus or bacteria, to induce an immune response against it. Based on the vaccination, the genetic material might be DNA or RNA; as such, it offers instructions for producing a specific pathogen protein that the immune system will perceive as foreign and mount an immune response. Nucleic acid vaccines for multiple antigens might be made in the same facility, lowering costs even more. Most traditional vaccine regimens do not allow for this. Herein, we demonstrate the recent understanding and advances in nucleic acid vaccines (DNA and mRNA based) against COVID-19, specifically those in human clinical trials.
\end{abstract}

Keywords: mRNA; COVID-19; DNA; nucleic acid; SARS-CoV-2; vaccine; coronavirus

\section{Introduction}

A vaccine is the best approach for infectious disease prevention [1]. The first effective vaccine developed was against the smallpox virus in the form of live attenuated, and, through worldwide mass vaccinations, smallpox was declared eradicated [2]. Pasteur and his team coined the idea of attenuation and defended its use with pasteurella multocida, responsible for diarrhea in chickens. Later, anthrax vaccine in sheep and rabies vaccine in animals and humans were developed using the attenuation approach [3]. The concept of inactivation of a pathogen without losing immunogenicity was devised at the end of the 19th century. Later, various inactivated (killed, dead) vaccines were formulated against typhoid, cholera and plague diseases. Over time, various novel technology-based vaccines have been developed, such as diphtheria toxoid and recombinant technologybased hepatitis B vaccine [4]. Despite the success, vaccine development is still a challenging task as scale-up productions and funding resources have commonly hindered much of their development. This process is usually challenging, complex and takes 15-25 years for the final approved product, and by then, the patent life would have ended. It often requires expenses of more than $\$ 500$ million. Pre-COVID-19 era, only 7\% of the vaccines developed progressed to human clinical trials from pre-clinical studies [5]. Additionally, of those in clinical trials, only $20 \%$ show safety and efficacy [6]. Other considerations 
required for vaccine development are stability, storage conditions, number of injections, route of immunization, optimal dose, scale-up, manufacturing and distribution of the vaccine globally.

The novel coronavirus strain, severe acute respiratory syndrome coronavirus 2 (SARSCoV-2), emerged from Wuhan, China, in late December 2019 [7,8]. Rapidly, it spread around the globe and was declared a pandemic soon after [9].

In parallel, there was and is a worldwide race for vaccine discovery. A number of different modes of vaccine formulations have been developed at an unprecedented speed $[4,10]$, such as live attenuated, inactivated (dead), subunit, viral vector and genetic (nucleic acid), against the SARS-CoV-2 virus [11-13]. Currently, seven vaccines using three different approaches have been approved by the WHO for emergency authority use. Generally, the vaccine development process requires 15-25 years for approval. However, COVID-19 vaccines have been approved within 6-9 months in an accelerated development process in response to the pandemic situation [14]. In fact, the speed has been possible due to the method used for vaccine development in the instance of nucleic acid-based vaccines. These vaccine formulations have been around for over 30 years and tested in humans for a number of diseases, such as cancer, HIV and other viruses, but none have been approved for human use. However, the pandemic has enabled their use to be fast tracked, a technology that instigates revolution in the vaccine development process and overcomes the limitations of previously available technologies [15]. It involves the administration of nucleic acid coding for antigens in the body. This nucleic acid coding acts as a set of instructions and guides the host cells to produce antigenic proteins, which, subsequently, stimulate specific immune responses against the gene-delivered antigen. Thus, the nucleic acid vaccine immunizes the host against the specific pathogen [10]. Herein, we provide an overview of the current status of approved, as well as clinical developmental stage, nucleic acid-based vaccines for COVID-19.

\section{Structural Elements of COVID-19}

These viruses consist of large enclosed, positive single-stranded RNA as genetic material that infects various mammalian and avian species. The SARS-CoV-2 electron image showed a globular form, having a diameter of 60-140 nm and an outer surface adorned with unique 9-12 nm long glycoprotein spikes that give the resemblance of a solarium corona, hence their name, coronaviruses [16]. There are four key structural proteins involved in the membrane fusion, viral congregation, morphogenesis and discharge of virus particles (Figure 1) [17,18]. The S-protein is key in facilitating virus entry into host cells [18]. The viral genome encodes for the basic building-block structural proteins as well as a certain non-structural protein (nsp) that aids viral growth. The open reading frame (orf) region encodes nsp proteins, such as 3-chymotrypsinlikeprotease, papain-like protease and RNA-dependent RNA polymerase [19].

The RNA viral genome has a length from 26 to $32 \mathrm{~kb}$. The genetic material, i.e., RNA, has a cap at the $5^{\prime}$ end, a polyadenylated (A) loop at the $3^{\prime}$ end, two flanking untranslated regions (UTRs), and numerous orfs that encode multiple enzymes and proteins and operate as mRNA for replicase polypeptide translation. The genome is arranged in the order of noncoding 5'-UTR-replicase genes (orf1a/b)-structural proteins (S, E, M, and N) and accessory proteins-noncoding $3^{\prime}$-UTR. The orf $1 \mathrm{a} / \mathrm{b}$, located at the $5^{\prime}$-end of the genome, is the largest orf, and it encodes $15 \mathrm{nsps}$ (nsp1-10 and nsp12-nsp16) [20,21]. Because of ribosomal frameshifting, orf1a/b has overlapping orfs and creates two polypeptides: pp1a and pp1ab. The cleavage of the nonstructural protein is required for the viral lifecycle for RNA transcription and translation. Majorly, nsp4 cleave the LQ-SAG via 3CLpro, where nsp16 is also actively involved. On the other hand, nsp1, nsp2 and nsp3 cleavage is also facilitated by nsp4 via PLP2pro. RNA-dependent RNA polymerase (nsp12), Helicase (nsp13) and Exonuclease (nsp14) are the enzymes that aid the viral replication process in the host [22]. The viral genome comprises four structural proteins that are accountable for binding to the host, virus particles assembly, morphogenesis and viral release to infect 
the host [23]. Out of all four structural proteins, the novel coronavirus' envelop protein is smaller in size and is found in the endoplasmic reticulum-Golgi complex in the human host. The E, $\mathrm{M}$ and $\mathrm{N}$ proteins work together to promote the formation of virus-like particles [24]. The membrane protein is a viral transmembrane glycoprotein that is 100 times more abundant than the envelope glycoproteins. The $\mathrm{M}$ protein, like the $\mathrm{E}$ and $\mathrm{N}$ proteins, plays an important role in viral assembly. The $\mathrm{N}$ protein is in charge of encapsulating the viral genome RNA in a helical ribonucleocapsid [25-27].

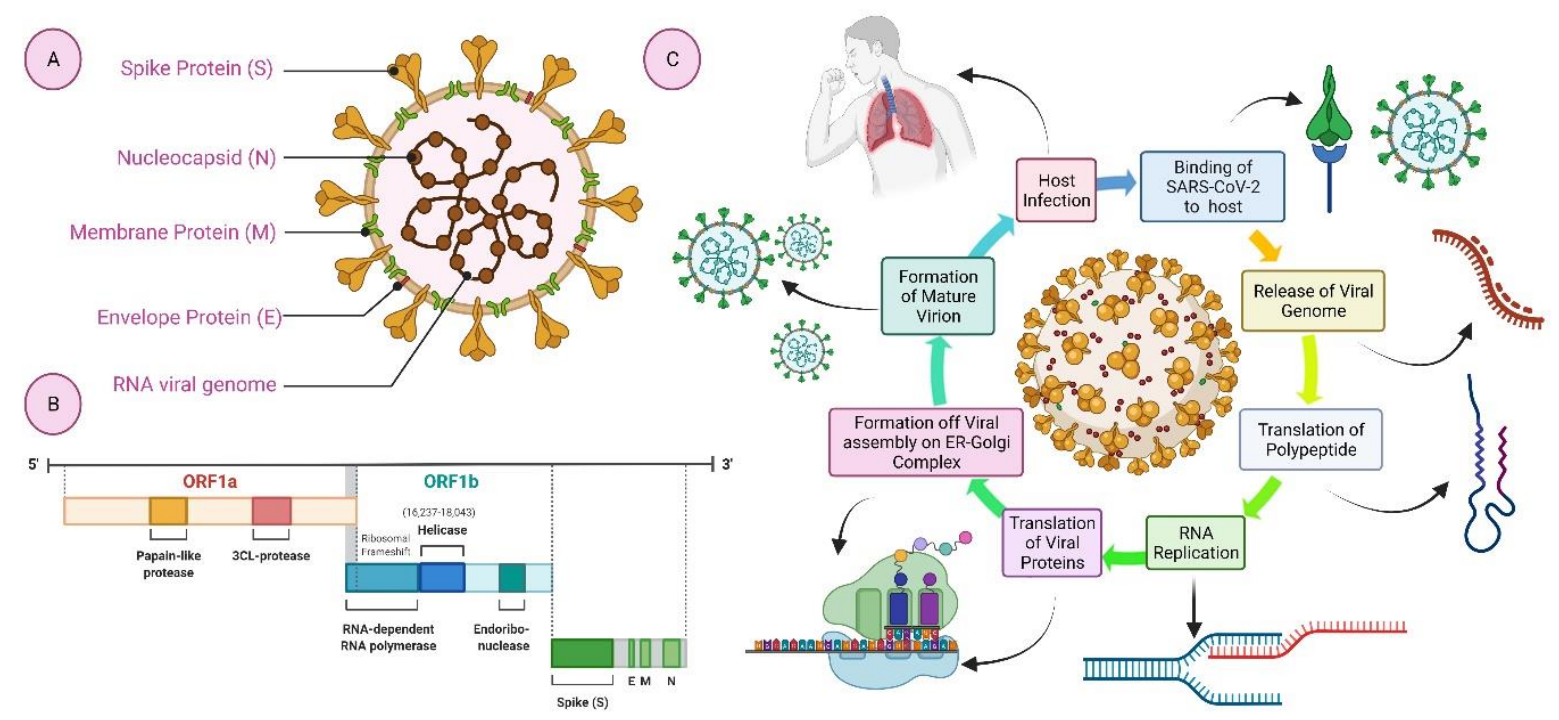

Figure 1. SARS-CoV-2 structural elements, genetic makeup and viral life cycle overview. (A) Structural organization of novel coronavirus; (B) Genomicmap of the novel coronavirus; (C) Lifecycle of novel coronavirus.

\section{Immunopathophysiology of COVID-19}

Approximately $80 \%$ of SARS-CoV-2 infected cases are asymptomatic or mild, $15 \%$ require oxygen supply and 5\% require ventilation [28]. It has been documented that SARS$\mathrm{CoV}-2$ infection activates cell-mediated and humoral immune responses and initiates the release of pro-inflammatory cytokines in critical and severe COVID-19 patients, resulting in abnormalities in the functions of granulocytes, monocytes and lymphocytes [29,30]. This dysfunction in immune responses may cause the superinfection of other pathogens, cytokine storm and organ damage and failure in some individuals. The principal mechanisms for immunological modulation may be the depletion of lymphocytes, increased neutrophils, cytokine storms and antibody-dependent enhancement [31]. The immunopathophysiology of COVID-19 suggested that the Spike protein expressed on the surface of SARS-CoV-2 facilitates its entry into the host airway epithelial cells via its binding with angiotensinconverting enzyme 2 (ACE2) (Figure 2) [32-34]. There is a recruitment of antigen-presenting cells (alveolar macrophages and dendritic cells) to the site of infection, which endocytose the virus and process and present small peptide fragments on its surface for the stimulation of CD4 and CD8 T-cells [35]. This results in stimulation of B cells for antibody production and stimulation of CD4 and CD8 T-cells for the secretion of cytokines. In some individuals, the rapid secretion of pro-inflammatory cytokines, such as TNF $\alpha$, IL-6 and IL-1b in a short duration leads to cytokine storm, which adversely affects the essential organs of patients. It has been suggested that SARS-CoV-2 may directly obliterate the lymphatic organs, such as the spleen and lymph nodes [36]. High levels of lactic acid have also been noted in patients with COVID-19, which may attenuate lymphocyte proliferation [37]. In addition, due to infection, increased neutrophil counts and lymphopenia have been reported in COVID-19 patients $[38,39]$. 


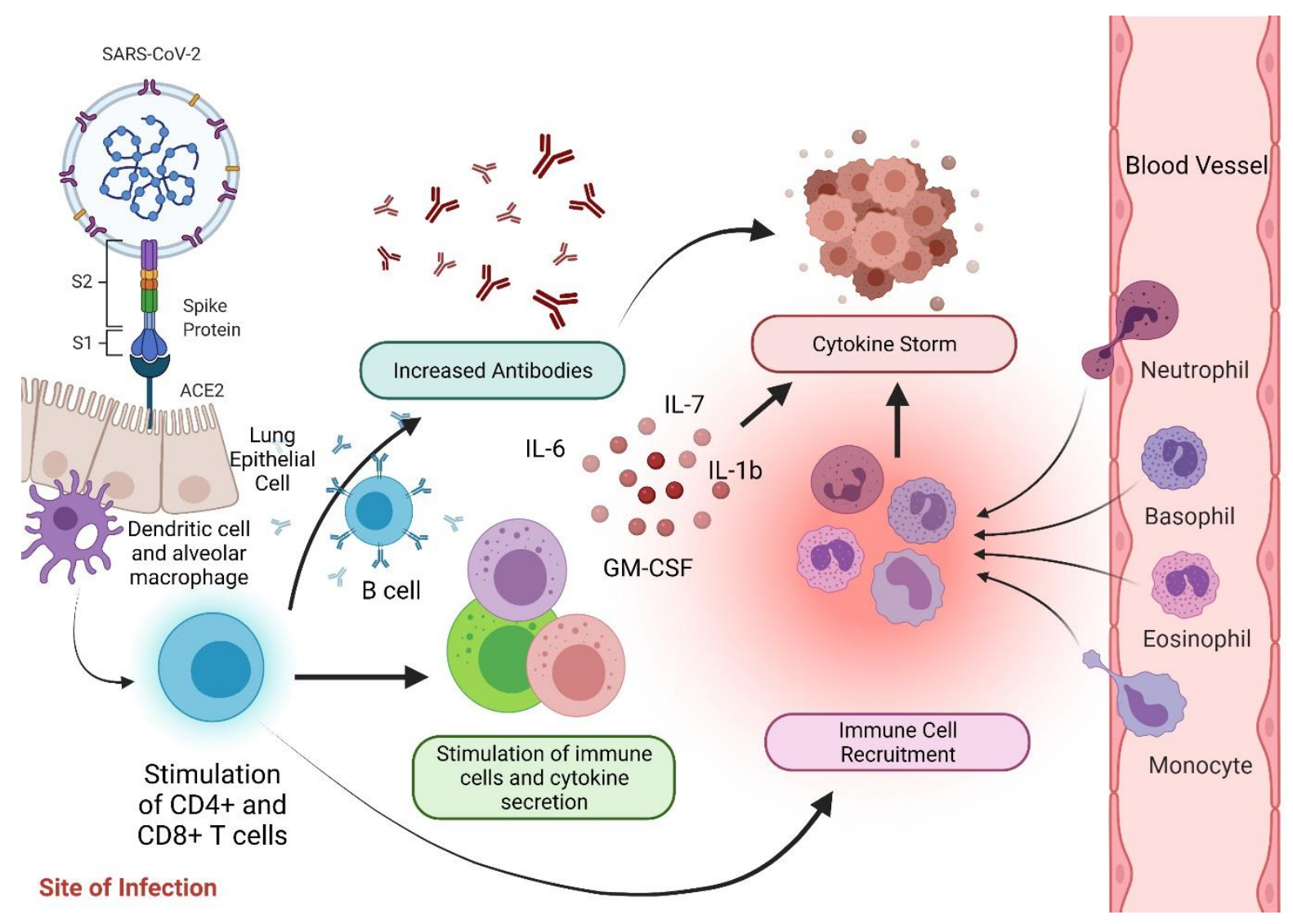

Figure 2. The immunopathology of COVID-19.

Following infection with SARS-CoV-2, T-helper (Th1) cells initiate the immune response and activate CD4+ T-cells to secrete GM-CSF and activate CD16+ and CD14+ monocytes to secrete IL-6 and contribute to inflammation [40]. Previously reported studies on single-cell analysis noted that immune cell interaction is identified by an increased number of IL-1 $\beta+$ and CD14+ monocytes in patients with COVID-19, which would contribute to secreted IL-1 $\beta$ [41]. Furthermore, studies suggest that increased neutrophils and monocytes/macrophages are recruited at the site of infection to stimulate IL-17 cytokine secretion by Th17 cells and further contribute to the inflammatory cascade [42]; Th17 cells have been reported in patients with COVID-19 [43]. However, the direct role of monocytes/macrophages in cytokine storm is unclear in patients with COVID-19 [44]. Additionally, eosinophils play a role during COVID-19 and secrete a large amount of inflammatory mediators [45]. Moreover, antibody-dependent enhancement of virus infection is of concern. Anti-viral antibodies enhance viral entry into host cells and, in some cases, enhance the replication of viruses into cells via Fc and/or complement receptors. Such phenomenon has been noted with Dengue and Ebola viruses $[46,47]$ and has also been noted in patients with COVID-19. However, further clinical evidence is required.

\section{Anti-SARS-CoV-2 Vaccines}

The most common and obvious antigens used in anti-SARS-CoV-2 is the Spike Sprotein, although other functional and non-structural molecules are also deemed as effective targets [48]. The push for vaccine development is to develop 'herd protection' [49,50]. A number of technologies used for SARS-CoV-2 vaccines are demonstrating efficacy and safety in relatively large clinical trials [51,52]. Several therapeutic and vaccination techniques have been used for other pathogens that could be translated to SARS-CoV-2. According to the $\mathrm{WHO}$, there are 287 vaccine candidates in development, out of which 102 are in the clinical development stage [53-55]. Platforms include dead virus, live-attenuated 
virus, nanoparticles or virus-like particles, nucleic acids and subunit vaccines (recombinant protein), and other than the live-attenuated virus vaccines, all the others require an adjuvant or an appropriate delivery system to stimulate immune responses [49,56]. On 15 February 2020, the very first vaccine investigation toward COVID-19 was conducted in China, utilizing genetically manipulated dendritic cells containing architectural and enzymatic proteins from SARS-CoV-2. On a similar path, a second vaccine trial was conducted with antigen-specific T cells. Whilst both vaccine candidates were tested therapeutically in patients with COVID-19. In order to obtain a strong immune response, scientists have also tried the protein subunit vaccine using the viral Spike protein, especially the proteins in the receptor-binding domain (RBD) [57,58].

\subsection{Nucleic Acid-Based Vaccines}

Nucleic acid vaccines focus on nucleic acid manipulation to build DNA or RNA vaccines (Table 1). Though several DNA vaccines have been used in animal studies over the past few decades, it has not been approved for use in humans [59]. DNA and RNAbased vaccines are easy to construct, which allows their quick development as vaccines. The genome encoding for a particular protein can be easily created as DNA or RNA and introduced into human cells to produce multiple copies of the immunostimulatory viral antigenic proteins [60]. These antigens, which are primarily encoded by the nucleic acid, can elicit both humoral and cell-mediated immune responses upon expression following cellular uptake (Figure 3) [61-63]. Because it provides convenient maneuvering and modification of the antigen, nucleic acid-based immunization technology can be considered adaptable and dynamic. The benefit of generating antigens in specific receptors is that it mimics protein synthesis throughout infection because the protein remains localized in the cell membrane, and protein alteration mechanisms, such as glycosylation, can occur to a large extent [64]. Prominently, they aid in the delivery of the desired antigen, regardless of whether that is derived from bacteria, parasites or viruses, thereby enabling the exchange of immunizations against a variety of pathogens [63]. The nucleic acid vaccines are having self-adjuvating properties hence can stimulate both adaptive (antigen-based) and innate immune responses, while most other vaccine types need an adjuvant to achieve a similar goal [65]. After injection, RNA vaccines only have to cross the plasma membrane but not the nuclear envelope, which is applicable to DNA vaccines. Recognition and expounding the uptake route are critical for the development of more effective nucleic acid vaccines. Once the nucleic acid vaccine is encountered by dendritic cells (DCs), which then produce and present antigen to T-cells in order to activate the adaptive immune response. Inside DCs, mRNA binds to Toll-like receptor 7, while DNA with Toll-like receptor 9 for the activation of Interferon 1 and Th1 cells [66]. Similarly, the nucleic acid vaccine candidate can be presented to the MCH-II molecule on myocytes post-translation to induce adaptive immune response [67]. The outer layer of a lipid nanoparticle can be adorned with specific targeting entities that direct the vaccine to specific tissues or cells, such as professional APCs or Langerhans cells in the epidermis, facilitating mRNA vaccine uptake by the desired type of immune cell and ultimately leading to an enhanced immune response against the antigen of choice [63]. Intravenous administration of DNA will sequentially reach secondary lymphatic organs, whereas intramuscular administration of a DNA vaccine enhanced by electroporation will primarily result in myocyte delivery. Myocytes will then synthesize and secrete the nascent antigen, which will be taken up by APCs, which will initiate adaptive immune responses [68]. 
Table 1. Nucleic acid-based vaccine candidates for SARS-CoV-2 in different stages of clinical development.

\begin{tabular}{|c|c|c|c|c|c|}
\hline Vaccine Name & Innovator/Country & $\begin{array}{l}\text { Vaccine } \\
\text { Platform }\end{array}$ & $\begin{array}{l}\text { Vaccine-Triggered } \\
\text { Immune Response }\end{array}$ & $\begin{array}{l}\text { Stage of Clinical } \\
\text { Development }\end{array}$ & $\begin{array}{l}\text { Clinical Trial ID Number } \\
\text { (https://covid19.trackvaccines. } \\
\text { org/vaccines/79/)- } \\
\text { Accessed on } 18 \text { August 2021) }\end{array}$ \\
\hline \multirow{3}{*}{ mRNA-1273 } & \multirow{3}{*}{ Moderna/USA } & \multirow{3}{*}{ RNA-based } & \multirow{3}{*}{$\begin{array}{l}\text { Post-administration of } \\
\text { mRNA vaccine, there is a } \\
\text { trigger of type-1 interferon } \\
\text { production, which } \\
\text { subsequently promotes the } \\
\text { Th1 response that is the } \\
\text { characteristic of actual viral } \\
\text { infection [69-71]. The innate } \\
\text { immune responses from } \\
\text { helper T-cells prime both } \\
\text { CD8+ and CD4+ T cells to } \\
\text { differentiate into effector } \\
\text { and memory subsets [72]. }\end{array}$} & \multirow{3}{*}{$\begin{array}{c}\text { Emergency use } \\
\text { approved (EUA) in } 72 \\
\text { Countries. This vaccine } \\
\text { is also manufactured by } \\
\text { Takeda (TAK-919) }\end{array}$} & $\begin{array}{c}\text { PHASE 1: } \\
\text { NCT04813796, } \\
\text { NCT04785144, } \\
\text { NCT04839315, } \\
\text { NCT04889209, } \\
\text { NCT04283461 }\end{array}$ \\
\hline & & & & & $\begin{array}{c}\text { PHASE 2: } \\
\text { ISRCTN73765130 } \\
\text { NCT04847050, } \\
\text { NCT04889209, } \\
\text { NCT04649151, } \\
\text { NCT04748471, } \\
\text { NCT04761822, and NCT04405076 } \\
\text { NCT04894435 } \\
\text { NCT04796896 }\end{array}$ \\
\hline & & & & & $\begin{array}{c}\text { PHASE 3: } \\
\text { NCT04860297, } \\
\text { NCT04649151, NCT04811664, } \\
\text { and NCT04470427 } \\
\text { NCT04796896 } \\
\text { NCT04805125 } \\
\text { NCT04806113 }\end{array}$ \\
\hline \multirow{3}{*}{$\begin{array}{l}\text { BNT162b2 } \\
\text { (Tozinameran, } \\
\text { Comirnaty) }\end{array}$} & \multirow{3}{*}{$\begin{array}{c}\text { Pfizer \& } \\
\text { BioNTech/USA }\end{array}$} & \multirow{3}{*}{$\begin{array}{l}\text { RNA-based (Encodes a } \\
\text { prefusion stabilized, } \\
\text { membrane-anchored } \\
\text { SARS-CoV-2 full-length } \\
\text { Spike protein) }\end{array}$} & \multirow{3}{*}{$\begin{array}{l}\text { The mRNA serves as an } \\
\text { antigen as well as an } \\
\text { adjuvant that will stimulate } \\
\text { both adaptive and innate } \\
\text { immune responses, } \\
\text { respectively. Toll-like } \\
\text { receptor } 7 \text { (TLR7) and } \\
\text { melanoma } \\
\text { differentiation-associated } 5 \\
\text { (MDA5) are triggered by } \\
\text { mRNA, which stimulates } \\
\text { S-protein-specific naive } \\
\text { T-cells, which become } \\
\text { activated and differentiated } \\
\text { into effector cells to form } \\
\text { cytotoxic T-lymphocytes or } \\
\text { helper T-cells. Strong Th1 } \\
\text { cell response helps in } \\
\text { antibody-secreting plasma } \\
\text { cells. Stimulation of the } \\
\text { type-1 interferon also aids in } \\
\text { T-cell memory [66,72-74] }\end{array}$} & \multirow{3}{*}{$\begin{array}{l}\text { EUA in } 99 \\
\text { countries. }\end{array}$} & $\begin{array}{c}\text { PHASE 1: } \\
\text { EUCTR2020-001038-36, and } \\
\text { NCT04380701 } \\
\text { NCT04839315, } \\
\text { NCT04889209, } \\
\text { NCT04816643 } \\
\text { NCT04588480 }\end{array}$ \\
\hline & & & & & $\begin{array}{c}\text { PHASE 2: } \\
\text { ISRCTN73765130 and } \\
\text { ISRCTN69254139 } \\
\text { EUCTR2020-001038-36, and } \\
\text { NCT04380701 } \\
\text { NCT04368728 } \\
\text { NCT04894435 } \\
\text { NCT04889209, } \\
\text { NCT04761822 and NCT04754594 } \\
\text { NCT04824638 } \\
\text { NCT04860739 and } \\
\text { EUCTR2021-001978-37 } \\
\text { NCT04649021 } \\
\text { NCT04588480 }\end{array}$ \\
\hline & & & & & $\begin{array}{c}\text { PHASE 3: } \\
\text { NCT04368728 } \\
\text { NCT04805125 } \\
\text { NCT04800133 } \\
\text { NCT04816669, } \\
\text { NCT04713553, and NCT04754594 }\end{array}$ \\
\hline $\begin{array}{l}\text { TAK-919 } \\
\text { (Moderna } \\
\text { formulation) }\end{array}$ & Takeda/Japan & RNA-based & $\begin{array}{l}\text { Post-administration of } \\
\text { mRNA vaccine, there is a } \\
\text { trigger of type-1 interferon } \\
\text { production, which } \\
\text { subsequently promotes the } \\
\text { Th1 response that is the } \\
\text { characteristic of actual viral } \\
\text { infection [69-71]. The innate } \\
\text { immune responses from } \\
\text { helper T-cells prime both } \\
\text { CD8+ and CD4+ T cells to } \\
\text { differentiate into effector } \\
\text { and memory subsets [72]. }\end{array}$ & EUA in 1 country. & $\begin{array}{l}\text { PHASE } 1 \text { and PHASE 2: } \\
\text { NCT04677660 }\end{array}$ \\
\hline
\end{tabular}


Table 1. Cont

\begin{tabular}{|c|c|c|c|c|c|}
\hline Vaccine Name & Innovator/Country & $\begin{array}{l}\text { Vaccine } \\
\text { Platform }\end{array}$ & $\begin{array}{l}\text { Vaccine-Triggered } \\
\text { Immune Response }\end{array}$ & $\begin{array}{l}\text { Stage of Clinical } \\
\text { Development }\end{array}$ & $\begin{array}{c}\text { Clinical Trial ID Number } \\
\text { (https://covid19.trackvaccines. } \\
\text { org/vaccines/79/)- } \\
\text { Accessed on } 18 \text { August 2021) }\end{array}$ \\
\hline \multirow{3}{*}{ mRNA } & \multirow{3}{*}{ Walvax/China } & \multirow{3}{*}{ RNA-based } & \multirow{19}{*}{$\begin{array}{l}\text { Post-vaccination, the mRNA } \\
\text { binds with TLR7 and MDA5, } \\
\text { which triggers IFN1 } \\
\text { production along with a } \\
\text { strong Th1 cell response that } \\
\text { helps in antibody-secreting } \\
\text { plasma cells [66,72]. }\end{array}$} & $\begin{array}{l}\text { Under trials in } 4 \\
\text { countries. } \\
\text { Phase } 1: 2 \text { trials }\end{array}$ & $\begin{array}{c}\text { PHASE 1: } \\
\text { ChiCTR2000034112, and } \\
\text { ChiCTR2000039212 }\end{array}$ \\
\hline & & & & Phase 2: 1 trial & $\begin{array}{c}\text { PHASE 2: } \\
\text { ChiCTR2100041855 }\end{array}$ \\
\hline & & & & Phase 3: 1 trial & $\begin{array}{c}\text { PHASE 3: } \\
\text { NCT04847102 }\end{array}$ \\
\hline \multirow{3}{*}{ CVnCov } & \multirow{3}{*}{ Curevac/Germany } & \multirow{3}{*}{ RNA-based } & & $\begin{array}{c}\text { Under trials in } 12 \\
\text { countries. } \\
\text { Phase } 1: 1 \text { trials }\end{array}$ & $\begin{array}{c}\text { PHASE 1: } \\
\text { NCT04449276 }\end{array}$ \\
\hline & & & & Phase 2: 4 trials & $\begin{array}{c}\text { PHASE 2: } \\
\text { ISRCTN73765130 } \\
\text { 2020-003998-22 } \\
\text { NCT04652102 } \\
\text { NCT04515147, } \\
\text { PER-054-20 }\end{array}$ \\
\hline & & & & Phase 3: 6 trials & $\begin{array}{c}\text { PHASE 3: } \\
\text { NCT04838847 and NCT04848467 } \\
\text { NCT04860258 } \\
\text { EUCTR2020-004066-19, and } \\
\text { NCT04674189 and } \\
\text { NCT04652102 } \\
2020-003998-22\end{array}$ \\
\hline \multirow{3}{*}{ BNT162b1 } & \multirow{3}{*}{$\begin{array}{c}\text { Pfizer \& } \\
\text { BioNTech/USA }\end{array}$} & \multirow{3}{*}{$\begin{array}{l}\text { RNA-based } \\
\text { (Nucleoside-modified } \\
\text { mRNA vaccine that } \\
\text { encodes the trimerized } \\
\text { receptor-binding } \\
\text { domain) }\end{array}$} & & $\begin{array}{l}\text { Under trials in } 5 \\
\text { countries. } \\
\text { Phase } 1: 2 \text { trials }\end{array}$ & $\begin{array}{c}\text { PHASE 1: } \\
\text { EUCTR2020-001038-36, and } \\
\text { NCT04380701 } \\
\text { ChiCTR2000034825, and } \\
\text { NCT04523571 }\end{array}$ \\
\hline & & & & Phase 2: 2 trials & $\begin{array}{c}\text { PHASE 2: } \\
\text { EUCTR2020-001038-36, and } \\
\text { NCT04380701 } \\
\text { NCT04368728 }\end{array}$ \\
\hline & & & & Phase 3: 1 trials & $\begin{array}{c}\text { PHASE 3: } \\
\text { NCT04368728 }\end{array}$ \\
\hline MRT5500 & $\begin{array}{c}\text { Sanofi } \\
\text { Pasteur/USA }\end{array}$ & RNA-based & & $\begin{array}{l}\text { Under trials in } 1 \text { country. } \\
\text { Phase } 1 \text { and 2: } 1 \text { trial }\end{array}$ & $\begin{array}{l}\text { PHASE } 1 \text { and PHASE 2: } \\
\text { EUCTR2020-001038-36, } \\
\text { NCT04380701 }\end{array}$ \\
\hline EXG 5003 & $\begin{array}{l}\text { Elixirgen } \\
\text { Therapeutic } \\
\text { Inc./USA }\end{array}$ & RNA-based & & $\begin{array}{l}\text { Under trials in } 1 \text { country. } \\
\text { Phase } 1: 1 \text { trial } \\
\text { Phase } 2: 1 \text { trial }\end{array}$ & $\begin{array}{l}\text { PHASE } 1 \text { and PHASE 2: } \\
\text { NCT04863131 }\end{array}$ \\
\hline BNT162a1 & $\begin{array}{c}\text { Pfizer \& } \\
\text { BioN- } \\
\text { Tech/Germany }\end{array}$ & $\begin{array}{l}\text { RNA-based (Encodes an } \\
\text { optimized SARS-CoV-2 } \\
\text { receptor-binding } \\
\text { domain) }\end{array}$ & & $\begin{array}{l}\text { Under phase } 1 \text { and } \\
\text { phase } 2 \text { trials in } \\
\text { Germany }\end{array}$ & $\begin{array}{l}\text { PHASE } 1 \text { and PHASE 2: } \\
\text { EUCTR2020-001038-36, } \\
\text { NCT04380701 }\end{array}$ \\
\hline BNT162c2 & $\begin{array}{c}\text { Pfizer \& } \\
\text { BioN- } \\
\text { Tech/Germany }\end{array}$ & $\begin{array}{c}\text { RNA-based (A } \\
\text { candidate using } \\
\text { self-amplifying mRNA }\end{array}$ & & $\begin{array}{l}\text { Under phase } 1 \text { and } \\
\text { phase } 2 \text { trials in } \\
\text { Germany }\end{array}$ & $\begin{array}{l}\text { PHASE } 1 \text { and PHASE 2: } \\
\text { EUCTR2020-001038-36, } \\
\text { NCT04380701 }\end{array}$ \\
\hline BNT162b3 & $\begin{array}{c}\text { Pfizer \& } \\
\text { BioN- } \\
\text { Tech/Germany }\end{array}$ & $\begin{array}{c}\text { RNA-based (A } \\
\text { candidate using } \\
\text { self-amplifying mRNA }\end{array}$ & & $\begin{array}{l}\text { Under phase } 1 \text { and } \\
\text { phase } 2 \text { trials in } \\
\text { Germany }\end{array}$ & $\begin{array}{l}\text { PHASE } 1 \text { and PHASE 2: } \\
\text { NCT04537949, and } \\
\text { EUCTR2020-003267-26-DE }\end{array}$ \\
\hline DS-5670a & $\begin{array}{l}\text { Daiichi Sankyo } \\
\text { Co., Ltd./Japan }\end{array}$ & RNA-based & & $\begin{array}{c}\text { Under phase } 1 \text { and } 2 \\
\text { trial in Japan }\end{array}$ & $\begin{array}{l}\text { PHASE } 1 \text { and PHASE 2: } \\
\text { NCT04821674 }\end{array}$ \\
\hline Chulacov19 & $\begin{array}{l}\text { Chulalongkorn } \\
\text { Univer- } \\
\text { sity/Thailand }\end{array}$ & RNA-based & & $\begin{array}{c}\text { Under phase } 1 \text { and } \\
\text { phase } 2 \text { trial in Thailand }\end{array}$ & $\begin{array}{l}\text { PHASE } 1 \text { and PHASE 2: } \\
\text { NCT04566276 }\end{array}$ \\
\hline \multirow{2}{*}{$\begin{array}{l}\text { LUNAR- } \\
\text { cov19/ARCT-021 }\end{array}$} & \multirow{2}{*}{$\begin{array}{l}\text { Arcturus } \\
\text { Therapeutics } \\
\text { inc/USA }\end{array}$} & \multirow{2}{*}{ RNA-based } & & Phase 1: 1 trials & $\begin{array}{c}\text { PHASE 1: } \\
\text { NCT04480957 }\end{array}$ \\
\hline & & & & Phase 2: 3 trials & $\begin{array}{c}\text { PHASE 2: } \\
\text { NCT04668339 } \\
\text { NCT04728347 and NCT04480957 }\end{array}$ \\
\hline PTX-COVID19-B & $\begin{array}{l}\text { Providence } \\
\text { therapeutics } \\
\text { holding } \\
\text { Inc/Canada }\end{array}$ & RNA-based & & $\begin{array}{c}\text { Under phase } 1 \text { trial in } \\
\text { Canada }\end{array}$ & $\begin{array}{c}\text { PHASE 1: } \\
\text { PRO-CL-001, NCT04765436 }\end{array}$ \\
\hline
\end{tabular}


Table 1. Cont.

\begin{tabular}{|c|c|c|c|c|c|}
\hline Vaccine Name & Innovator/Country & $\begin{array}{l}\text { Vaccine } \\
\text { Platform }\end{array}$ & $\begin{array}{l}\text { Vaccine-Triggered } \\
\text { Immune Response }\end{array}$ & $\begin{array}{l}\text { Stage of Clinical } \\
\text { Development }\end{array}$ & $\begin{array}{c}\text { Clinical Trial ID Number } \\
\text { (https://covid19.trackvaccines. } \\
\text { org/vaccines/79/)- } \\
\text { Accessed on } 18 \text { August 2021) }\end{array}$ \\
\hline HDT-301 & $\begin{array}{c}\text { Senai } \\
\text { cimatec/Brazil }\end{array}$ & RNA-based & & Under phase 1 trial & PHASE 1: NCT04844268 \\
\hline mRNA-1283 & Moderna/USA & RNA-based & & $\begin{array}{c}\text { Under phase } 1 \text { trial in } \\
\text { America }\end{array}$ & $\begin{array}{c}\text { PHASE 1: } \\
\text { NCT04813796 }\end{array}$ \\
\hline $\begin{array}{l}\text { mRNACOVID19 } \\
\text { vaccine }\end{array}$ & $\begin{array}{l}\text { Stemirna } \\
\text { Therapeutics Co., } \\
\text { Ltd./China }\end{array}$ & RNA-based & & $\begin{array}{l}\text { Phase } 1 \text { trial in } 0 \\
\text { country. }\end{array}$ & $\begin{array}{c}\text { PHASE 1: } \\
\text { ChiCTR2100045984 }\end{array}$ \\
\hline $\begin{array}{c}\text { LNP- } \\
\text { nCoVsaRNA }\end{array}$ & Imperial/UK & RNA-based & & This vaccine is on hold & $\begin{array}{c}\text { PHASE 1: } \\
\text { ISRCTN17072692 }\end{array}$ \\
\hline \multirow{3}{*}{$\begin{array}{l}\text { AG0302- } \\
\text { COVID19 }\end{array}$} & \multirow{3}{*}{ AnGes/Japan } & \multirow{3}{*}{ DNA-based } & \multirow{3}{*}{$\begin{array}{l}\text { Post-vaccination, dsDNA } \\
\text { triggers TLR9 to induce } \\
\text { type-I interferon, which } \\
\text { stimulates S-protein-specific } \\
\text { naive T-cells, which become } \\
\text { activated and differentiated } \\
\text { into effector cells to form } \\
\text { cytotoxic T-lymphocytes or } \\
\text { helper T-cells }[66,72] .\end{array}$} & \multirow{3}{*}{$\begin{array}{l}\text { Under phase } 1,2 \text { and } 3 \\
\text { trials in Japan }\end{array}$} & $\begin{array}{c}\text { PHASE 1: } \\
\text { NCT04527081 }\end{array}$ \\
\hline & & & & & $\begin{array}{c}\text { PHASE 2: } \\
\text { NCT04655625 and NCT04527081 }\end{array}$ \\
\hline & & & & & $\begin{array}{l}\text { PHASE 3: } \\
\text { NCT04655625 }\end{array}$ \\
\hline \multirow{3}{*}{ ZyCoV-D } & \multirow{3}{*}{$\begin{array}{c}\text { Zydus } \\
\text { cadila/India }\end{array}$} & \multirow{3}{*}{ DNA-based } & \multirow{3}{*}{$\begin{array}{l}\text { Post vaccination dsDNA } \\
\text { triggers TLR9 to induce type } \\
\text { I interferon which stimulates } \\
\text { S-protein-specific naive T } \\
\text { cells, which become } \\
\text { activated and differentiated } \\
\text { into effector cells to form } \\
\text { cytotoxic T-lymphocytes or } \\
\text { helper T cells. Strong Th1 } \\
\text { cell response helps in } \\
\text { antibody-secreting plasma } \\
\text { cells. Stimulation of Type } 1 \\
\text { interferon also aids in T cell } \\
\text { memory [66,75]. }\end{array}$} & \multirow{3}{*}{ EUA in India } & $\begin{array}{c}\text { PHASE 1: } \\
\text { CTRI/2020/07/026352 } \\
\text { and CTRI/2021/03/032051 }\end{array}$ \\
\hline & & & & & $\begin{array}{c}\text { PHASE 2: } \\
\text { CTRI/2020/07/026352 } \\
\text { and CTRI/2021/03/032051 }\end{array}$ \\
\hline & & & & & $\begin{array}{c}\text { PHASE 3: } \\
\text { CTRI/2021/01/030416 }\end{array}$ \\
\hline \multirow{3}{*}{ INO-4800 } & \multirow{3}{*}{ Inovio/USA } & \multirow{3}{*}{ DNA-based } & \multirow{9}{*}{$\begin{array}{l}\text { Post-vaccination, dsDNA } \\
\text { triggers TLR9 to induce } \\
\text { type-I interferon, which } \\
\text { stimulates S-protein-specific } \\
\text { naive T-cells, which become } \\
\text { activated and differentiated } \\
\text { into effector cells to form } \\
\text { cytotoxic T-lymphocytes or } \\
\text { helper T-cells }[66,72] .\end{array}$} & \multirow{3}{*}{$\begin{array}{l}\text { Under phase } 1,2 \text { and } 3 \\
\text { trials in } 3 \text { countries }\end{array}$} & $\begin{array}{c}\text { PHASE 1: } \\
\text { NCT04336410 } \\
\text { NCT04447781 }\end{array}$ \\
\hline & & & & & $\begin{array}{c}\text { PHASE 2: } \\
\text { NCT04642638 } \\
\text { ChiCTR2000040146 } \\
\text { NCT04447781 }\end{array}$ \\
\hline & & & & & $\begin{array}{c}\text { PHASE 3: } \\
\text { NCT04642638 }\end{array}$ \\
\hline GX-19 & Genexine/Korea & DNA-based & & $\begin{array}{l}\text { Under phase } 1 \text { and } \\
\text { phase } 2 \text { trials in Korea }\end{array}$ & $\begin{array}{c}\text { PHASE } 1 \text { and PHASE 2: } \\
\text { NCT04715997 and NCT04445389 }\end{array}$ \\
\hline $\begin{array}{l}\text { AG0301- } \\
\text { COVID19 }\end{array}$ & AnGes/Japan & DNA-based & & $\begin{array}{l}\text { Under phase } 1 \text { and } 2 \\
\text { trials in } \\
\text { Japan }\end{array}$ & $\begin{array}{l}\text { PHASE } 1 \text { and PHASE 2: } \\
\text { NCT04463472 }\end{array}$ \\
\hline GLS-5310 & $\begin{array}{l}\text { GeneOne Life } \\
\text { Science } \\
\text { Inc./Korea }\end{array}$ & DNA-based & & $\begin{array}{l}\text { Under phase } 1 \text { and } 2 \\
\text { trials in } \\
\text { Korea }\end{array}$ & $\begin{array}{l}\text { PHASE } 1 \text { and PHASE 2: } \\
\text { NCT04673149 }\end{array}$ \\
\hline COVID-eVax & Takis/Italy & DNA-based & & $\begin{array}{l}\text { Under phase } 1 \text { and } 2 \\
\text { trial in Italy }\end{array}$ & $\begin{array}{l}\text { PHASE } 1 \text { and PHASE 2: } \\
\text { EUCTR2020-003734-20, and } \\
\text { NCT04788459 }\end{array}$ \\
\hline COVIGEN & $\begin{array}{l}\text { University of } \\
\text { Syd- } \\
\text { ney/Australia }\end{array}$ & DNA-based & & $\begin{array}{c}\text { Under phase } 1 \text { trial in } \\
\text { Australia }\end{array}$ & $\begin{array}{c}\text { PHASE 1: } \\
\text { NCT04742842 }\end{array}$ \\
\hline bacTRL-Spike & Symvivo/Australia & DNA-based & & $\begin{array}{c}\text { Under phase } 1 \text { trial in } \\
\text { Australia }\end{array}$ & $\begin{array}{c}\text { PHASE 1: } \\
\text { NCT04334980 }\end{array}$ \\
\hline
\end{tabular}




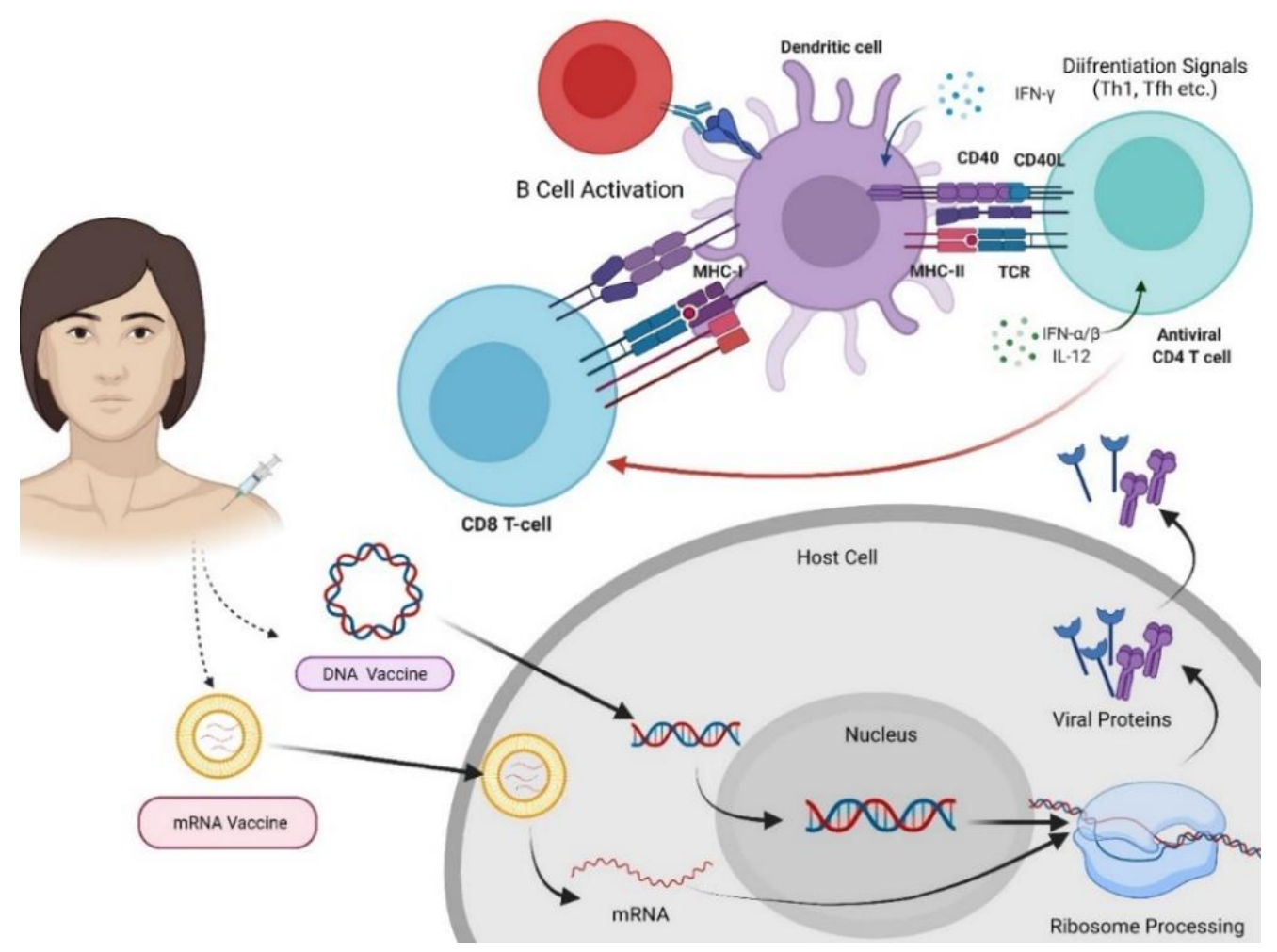

Figure 3. Mechanism of nucleic acid vaccine to generate immune protection post-vaccine jab.

\subsubsection{RNA Vaccines}

An RNA vaccine, also established as a messenger RNA (mRNA) vaccine, is a type of immunization that uses a replica of pre-existing mRNA to elicit an immune response. Pursuing immunization, RNA is transfected into immune cells and transformed into mRNA, allowing the host cells to produce extracellular protein [76]. The delivery of mRNA vaccines is effective when delivered in lipid nanoparticles as they target dendritic cells resulting in the stimulation of cellular and humoral immune responses [76-79]. Recent research and technological breakthrough (viz. codon optimization, modification of nucleotides, understanding roles of untranslated regions) have enabled mRNA a cogent vaccine platform by overcoming drawbacks, such as instability and immunogenicity $[76,80]$.

To date, there are 23 mRNA vaccines at various clinical developmental stages, of which three have been approved for emergency use against COVID-19 [53-55]. There are benefits of manipulating mRNA to allow host cells to produce the viral antigenic protein fragments, including the fact that mRNA is now simpler to produce than whole viral inactivation. Another advantage is the speed with which design and production can be completed. In just two days, Moderna developed an mRNA-1273 vaccine for COVID-19. Another benefit of RNA vaccines is that because the antigens are produced within the cell, they stimulate cellular and humoral immunity [81,82], and they have no effect on, nor do they reconfigure, DNA within the cell. The artificial mRNA segment is a copy of the viral RNA that contains the prompts for constructing the virus's antigen, which is completely irrelevant to the human genome. This misconception dispersed as the COVID-19 mRNA vaccines acquired widespread attention, and it is a debunked conspiracy theory [83]. It is a very safe, highly efficacious and non-infectious platform with no risk of insertional mutagenesis as it does not enter the nucleus. In addition, it is degraded by normal cellular processes, and the regulation of in vivo half-life can be manipulated [80,84,85]. Further, the intrinsic immunogenicity of the mRNA can be down-modulated to resolve safety concerns $[80,86,87]$. mRNA-1273 and Comirnaty (BNT162b2) have shown promising efficacy of $94.1 \%$ and $94.6 \%$, respectively, during phase 3 clinical trials $[73,88]$. However, naked mRNA is highly prone to degradation by extracellular RNases [89]. Hence, the 
construction of modified nucleosides and the presence of carrier molecules, such as lipid nanoparticles, are necessary to facilitate access of the mRNA into cells [78,86,87]. Despite the fact that mRNA-based vaccines induce both cellular and humoral immunity, multiple doses are required. It is significant to mention that anti-vector immunity does not develop (as observed in vector-based vaccines). As a result, the safety and efficacy of the multidose regime in mRNA vaccines are improved. The third advantageous feature is the vaccine's rapid development, low cost and scalability $[77,78,90,91]$. Finally, when a mutant strain of SARS-CoV-2 poses a risk in the future, it is simple to design and create an innovative mRNA vaccine out of an established one. Enhancing good manufacturing practice, institution regulations, and even further chronicling safety and expanding efficacy are all pharmacotherapy factors to consider and obstacles [78]. RNA vaccines can be administered in a variety of modalities, including standard needle injection or needlefree injections into the skin, injections into the blood, muscle, lymph nodes or directly into organs and nasal sprays. The precise manufacturing and delivery process of RNA vaccines varies according to the type. As mRNA products gain prominence in the vaccine domain, it is probable that specific guidelines will be established outlining the necessities for developing and testing new mRNA vaccines.

The human trials (phase 1) began for mRNA-1273 in March 2020 with 45 volunteers (18 to 55 Years) and the administration of $25 \mu \mathrm{g}, 100 \mu \mathrm{g}$ and $250 \mu \mathrm{g}$ doses. The second vaccination was administered 28 days after the first one [92]. The outcome depicted a dose-dependent humoral immune response. With $25 \mu \mathrm{g}$ and $100 \mu \mathrm{g}$ doses, a Th2 cytokine response is observed, while with a $100 \mu \mathrm{g}$ dose, a Th1 response is also observed [93]. A similar study was also conducted in 40 adults ( 56 to 71 years old) with either a $25 \mu \mathrm{g}$ or $100 \mu \mathrm{g}$ dose and demonstrated equal immunogenic responses as that of 18-55-year-old volunteers [94]. Phase 2 trials were conducted in 600 adults administrated either a 25 or the $100 \mu \mathrm{g}$ dose. Around July 2020, it entered Phase 3 trials in the US with 30,000 participants in a randomized, double-blind placebo-controlled study (NCT04470427). The primary objective of this study was to preclude symptomatic COVID-19, with secondary goals including SARS-CoV-2 infection prevention and COVID-19 hospitalization prevention. In November 2020, Moderna demonstrated safety and efficacy data of the vaccine candidates of the phase 3 study along with 2-month follow-up data and obtained the EUA from the USA followed by Canada [94]. Recently, it has been suggested by USFDA that there is an increased risk of myocarditis (inflammation of the heart muscle) and pericarditis (inflammation of the tissue surrounding the heart) following vaccination [95]. On 12 August 2021, the FDA amended the Moderna COVID-19 Vaccine EUA to allow for an additional dose to be given to certain immunocompromised individuals. Moderna also collaborated with Takeda in Japan with the enrolment of 200 individuals for a phase 1/2 study (NCT04677660); it is now EUA in Japan. The vaccine is approved by WHO, and it is approved for EUA in 72 countries.

The leading candidate mRNA framework is BNT162b2, which was devised by Pfizer in cooperation with BioNTech in Germany and Fosun Pharma in Shangai, China. The preclinical studies in the mice demonstrated efficient humoral and cellular immunity with a high titer of neutralizing antibodies along with a Th1 response [96]. Finally, the vaccinated animals did not show any clinical signs of disease. BNT162b1 and BNT162b2 were evaluated in phase 1 clinical trials (NCT04816643) with the enrolment of 4,644 individuals aged 18 to 85 . Indeed, a two-dose immunization with $30 \mu \mathrm{g} /$ doses of BNT162b1 was found to induce high titers of neutralizing anti-SARS-CoV-2 antibodies and virus-specific Th1 and CD8+ T-cell responses [97]. Randomized placebo-controlled phase $2 / 3$ trials were conducted with 43,998 participants in countries such as Argentina, Brazil, Germany, South Africa, Turkey and the United States of America to evaluate safety and efficacy (NCT04368728). In December 2020, it receives EUA from the USA, the UK, Europe and Canada. The vaccine is now approved by WHO, and it is approved for EUA in 100 countries. On 23 August 2021, USFDA approved the first COVID-19 vaccine, i.e., Comirnaty, for the prevention of COVID-19 disease in individuals 16 years of age and older [98]. 
The production of mRNA via in vitro transcription is quite compelling compared to producing plasmid DNA because it is a chemical process with no animal or cellular components (however, the cost may be higher), and the process can be easily molded as per cGMP norms $[63,99]$. The design of the manufacturing process begins with the in silico design of mRNA vaccines, which is accompanied by the development of plasmid DNA templates via molecular cloning or synthesis. After purification, mRNA is exchanged into a final storage buffer or formulated with the delivery system for use. To assess the quality of pilot mRNA vaccine batches, in-process analytic and potency tests are performed. Pilot mRNA vaccine batches can be tested in the immunogenicity and/or disease animal models if necessary. The final mRNA vaccine is scaled up and manufactured using a generic process with few modifications, tested quickly, and shipped for use [77]. The stabilization of mRNA as a drug product in a vial is distinct from the stability in vivo, and any formulations or delivery devices are important factors in the ultimate stabilization as a delivered product [100]. Enhancing the potency of an mRNA-based vaccine focuses on increasing the potency via increased stability and greater expression of the protein. A potency test is used to confirm that the mRNA can be translated into the desired protein product after being delivered to target cells. The manufacturing process may be slightly modified to meet modified nucleosides, capping strategies or purification protocols, depending on the specific mRNA construct.

\subsubsection{DNA Vaccines}

Using non-replicating plasmid DNA encoding, a viral protein has an advantage over traditional live-attenuated vaccines, as no infectious agent is involved. Initial findings by Wolf et al. in 1990 of plasmid or naked DNA injection into muscle cells of mice showed that protein can be expressed in the muscles, and subsequent studies showed that plasmid DNA can induce antibody and T-cell responses. These initial studies revolutionized the use of DNA in vaccines [101,102]. A total of 11 DNA-based COVID-19 vaccines have been designed and are currently in human clinical trials, including those produced by Inovio Pharmaceuticals, Genexine Consortium, Zydus Cadila and Symvivo, with the safety profile and immunity reported.

On 20 August 2021, the Drug Controller General of India approved ZyCoV-D from Zydus Cadila with EUA for people 12 years and above, and it is the first DNA vaccine ever approved for mankind [103]. The ZyCoV-D plasmid DNA vaccine by the Indian company Zydus Cadila encodes the Spike protein-induced neutralizing antibody responses and T-helper-1 pro-inflammatory interferon-gamma responses in mice, guinea pigs and rabbits [75]. The pVAX-1 vector is used in conjunction with a specific order encoding S-protein from the Wuhan strain of SARS-CoV-2. Over 28,000 volunteers participated in the phase 3 clinical trial study, with more than 50 clinical sites across India. It shows promising results against the delta variant of SARS-CoV-2. The trial was carried out successfully on 1000 children aged 12 to 18 years, and the plasmid DNA vaccine was found to be safe and effective. The preliminary analysis in symptomatic RT-PCR positive cases revealed that ZyCoV-D had a primary efficacy of approximately $66.6 \%$. The third dose of the vaccine proved to be $100 \%$ effective against moderate disease [104]. The study regimen comprises of four trial arms, with volunteers in the first and third treatment arms receiving the dose via a needle-based injection system of $1 \mathrm{mg}$ and $2 \mathrm{mg}$, respectively, and volunteers in the second and fourth treatment arms receiving the dose via a needle-free injection system of $1 \mathrm{mg}$ and $2 \mathrm{mg}$ (Tropis). In the study, $0.5 \mathrm{~mL}$ of ZyCoV-D vaccine containing $5 \mathrm{mg}$ of DNA plasmid with Spike protein gene region insert suspended in phosphate-buffered saline was administered. The seroconversion rate in volunteers was determined using IgG titers at day 84 , and approximately $36.36 \%, 33.33 \%, 100 \%$ and $80 \%$ of subjects were found to be seroconverted in each of the four treatment arms [105].

Inovio developed a DNA-based vaccine (INO-4700) for MERS-CoV, and in a phase 1 human clinical trial, it was shown to be well tolerated and high antibody and T-cell responses were induced in $95 \%$ of the participants and maintained at least 60 weeks after the 
final injection [106]. The INO-4800 DNA-based COVID-19 vaccine expressing the S-protein induces neutralizing antibody responses and T-cells in mice and guinea pigs [106,107]. In a phase 1 clinical trial, INO-4800 was well tolerated, safe and stimulated humoral and/or cellular immune responses in all 38 participants (NCT04336410) [108]. Genexine consortium developed GX-19N DNA vaccine expressing SARS-CoV-2 Spike and nucleocapsid antigens and are currently recruiting healthy participants for a phase I/IIa clinical trial to evaluate safety, tolerability and immunogenicity following intramuscular injection. The phase I clinical trial is a single-arm open-labeled study and will include 20 participants, whereas the phase 2a study is a randomized, double-blind placebo-controlled study of 150 participants. The start date was 30 December 2020, and the completion date will be 30 March 2022 (NCT04715997). In addition, Symvivo has used their bacTRL platform technology to deliver plasmid DNA encoding the Spike antigen (bacTRL-Spike) and are currently recruiting 12 healthy participants for a phase 1 clinical trial (NCT04334980). The AG0301-COVID19 vaccine by AnGes/Takara Bio/Osaka University entered a phase 1 clinical trial (NCT04463472) with 30 healthy adults aged 20-65, comprising two arms of a low dose $(1 \mathrm{mg}, \mathrm{n}=15)$ and a high dose $(2 \mathrm{mg}, \mathrm{n}=15)$ injected intramuscularly. In addition, the Covigenix VAX-001 plasmid DNA vaccine by Entos Pharmaceuticals is currently recruiting for a randomized phase 1/2 clinical trial (NCT04591184) with 72 healthy subjects to determine its safety, tolerability and immunogenicity following two intramuscular injections. Furthermore, CORVax, Spike protein plus IL-12 plasmid DNA vaccine is in a phase 1 clinical trial (NCT04627675) in healthy adults aged 18-50 and will be compared to those above 50 years old; the estimated completion date is May 2022. On 17 December 2020, the GLS-5310 vaccine entered a phase $1 / 2$ a clinical trial to assess safety, tolerability and immunogenicity using two doses of $0.6 \mathrm{mg}$ or $1.2 \mathrm{mg}$ (NCT04673149).

Regarding the manufacturing of a DNA vaccine, one of its strengths has been regarded as the production of plasmid DNA, producing a platform technology in which the same procedure could primarily be used irrespective of the gene encoded [109]. The DNA plasmids were optimized by experimenting with different promoters, including CpG motifs, codon optimization, and so on. Furthermore, the bacterial fermentation procedure is simple because the product is a plasmid grown in bacteria, such as Escherichia coli, and the plasmid DNA is relatively stable, making purification simple. This is in contrast to the time-consuming process of developing previous generation vaccines, which required finding ways to grow the pathogen, such as weakening or inactivating it [62]. The advancement of recombinant DNA technology has made it simple to scale-up the entire process with a robust and high-quality end product. However, proper folding and posttranslational modifications remain the ultimate challenge in process design. The addition of immunomodulators, adjuvants or delivery systems to the formulations may increase the complexity and cost of manufacturing. Injecting through gene guns or Pharmajet devices, such as Tropis and Stratis, directly results in the transfection of skin or muscle cells [110]. Using the electroporation technique, pores are formed in the cells on the application of an electric field, which is temporary for ease of transfection of the DNA plasmid in cells [111].

\section{Advantages of Nucleic Acid-Based Vaccines}

Upon immunization, nucleic acid-based vaccines imitate a viral infection, causing vaccine antigens to be expressed in situ, which tends to result in the initiation of both humoral and cytotoxic T-cell responses [112]. Nucleic acid-based anti-SARS-CoV-2 vaccines may have advantages over traditional vaccines for the following reasons: (i) The high potency of mRNA vaccines is capable of generating potent antiviral neutralizing antibodies by activating both CD4+ and CD8+ T-cells with only one or two low-dose immunizations $[113,114]$. (ii) The structural modification of mRNA results in higher immunogenicity by improving its stability and translation efficacy [113]. (iii) Because of its degradation process in cells, mRNA-based vaccines reduce the risk of infection and insertion-induced mutagenesis [115] (iv) These vaccines are easier to design in roughly a day and are also easy to produce on a large scale [116]. (v) Nucleic acid vaccine candidates generate strong protection via 
antibody generation and activating the cell-based immune pathways [117]. (vi) These vaccine candidates, particularly DNA vaccines, have a great amount of shelf-life stability and elicit a potent immune response [102,107]. (vii) Considering the pandemic situation and global vaccine demands to eradicate the same, these vaccines can be scaled up and mass-produced easily as compared to the conventional vaccine formulations [107]. These vaccine candidates have demonstrated sound immune response with potential efficacy against the novel coronavirus in clinical trials thus far.

\section{Challenges for Nucleic Acid Vaccine Development}

Vaccines comprising nucleic acids, such as DNA in the form of plasmids and RNA in the form of mRNA, have received significant attention in recent years in the generation of new, improved vaccines [118-120]. DNA vaccines contain genes that are delivered to the host either as 'naked' DNA or via a plasmid or vector. On the other hand, mRNA-based vaccines comprise mRNA that encodes a protein and are either non-replicating mRNA, in vivo self-replicating mRNA or, in vitro dendritic cell non-replicating mRNA [121,122]. Nucleic acid vaccines exhibit significant advantages over traditional vaccines in terms of efficacy, safety and induction of both arms of immunity, humoral and cell-mediated immune responses $[78,102,123]$.

However, both DNA and mRNA-based vaccines are associated with several challenges that need to be addressed during vaccine development to ensure their quality and effectiveness.

DNA vaccines can change the genetic composition of the host. DNA vaccines are delivered into the nucleus of the cell and transcribed into mRNA, which enters the cytoplasm, and the cells make the antigen. As such, DNA vaccines are associated with the risk of altering the genetic makeup of the host cell permanently (insertional mutagenesis). mRNA-based vaccines do not pose this risk as they do not enter the nucleus [123,124].

- Naked DNA has low immunogenicity, and it is essential to include vectors, adjuvants and appropriate delivery methods to increase its immunogenicity.

$\checkmark$ DNA vaccines are relatively cheap to produce compared to protein-based vaccines and are stable, making them viable for storage and worldwide distribution. The challenge for DNA-based vaccines is their poor immunogenicity, often requiring multiple booster injections.

mRNA needs to cross the cell membrane to enter the cytoplasm. This is challenging due to its extremely large size, the negative charge of the molecule and degradability. Manufacturing clinical-grade mRNA is also a challenging task.

With the emergence of the recent COVID-19 pandemic, a significant number of DNA ( 26 candidates) and mRNA ( 35 candidates) vaccines (Table 1$)$ are in preclinical and clinical trials despite these limitations, and eventually, two vaccines have been approved from the mRNA platform for mass application [125,126], and one from DNA platform, i.e., ZycovD (Zydus Cadila, India), has been approved [104].

- The Pfizer-BioNTech and Moderna vaccines have demonstrated very good efficacy and safety in human trials, despite the evidence of increased risk of blood clots in a small number of subjects. However, the long-term safety, vaccine stability and efficacy still need to be established for this platform and is a subject matter of future studies.

- The efficacy of nucleic acid-based vaccines is hindered by viral mutations, and the approved mRNA vaccines have demonstrated variable reduced efficacy against these mutant strains as compared with the efficacy against original non-mutated strains $[125,126]$. As viruses are known to mutate, mutations will continue with the SARS-CoV-2 virus, and hence, constant modifications of the vaccine are required to be effective against the new variants.

- Some studies have shown that mutations in the target proteins of the SARS-CoV-2 virus may lead to the development of drug and vaccine resistance and eventually lead to vaccine in-efficacy. 
The mRNA-based vaccines have the advantage of being stable, cost-effective, easy to make, and there are no requirements of purification steps that are commonly used for protein-based vaccines. However, it requires ultra-cold storage limiting its worldwide distribution, and a few booster shots may be required to generate appropriate immunity [62,127,128].

- The elevated immune response induced by mRNA in the cytoplasm might cause cells to secrete greater portions of type-I IFN and other interferons, which can inhibit mRNA translation and inevitably lead to translational stagnation, RNA degradation, reduced activation of CD8 (cluster of differentiation 8) + T-cells and ultimately immune response cessation $[65,78,85]$.

\section{The Future of Nucleic Acid Vaccines}

Researchers believe this is science's make-or-break era as gene-based vaccinations are produced and tested at breakneck speeds to overcome COVID-19. According to a study in over 365,000 homes in the UK, a single injection of the Pfizer vaccine reduced an individual's chance of spreading SARS-CoV-2 to their closest contacts by half. DNA and mRNA vaccine innovation will continue to be used around the world, and vaccines will quickly be developed against new emerging pathogens. However, we cannot expect it to completely replace current vaccine technologies anytime soon [129]. DNA and RNA vaccines are particularly intriguing as they are developed fairly quickly, which is a significant advantage for dealing with epidemics. They are, however, a new class of vaccines being approved for emergency use [130]. However, long-term safety studies are required for their application. More pharmacovigilance data are required, including the efficacy in the general population and side effects. Thus far, the evidence is promising. Despite the fact that adverse reactions are much more prevalent with COVID-19 vaccines than for other vaccinations, they appear to be more frequent with COVID-19 than that of other vaccines in clinical trials. Over $80 \%$ of individuals who received the mRNA vaccine had some form of a systemic reaction, including fatigue, muscle pain, fever, etc. [131,132]. Two of the most common sources of reactogenicity are impurities in vaccine manufacturing and the delivery platform. The solution to these issues is to have a self-amplifying RNA vaccine. A nucleic acid-based vaccine generated either from the positive-strand or negativestrand RNA viruses is known as self-amplifying RNA or RNA replicon. In all these RNA viruses, the gene sequences producing structural proteins are substituted by mRNA coding antigens of interest, as well as RNA polymerase for replication and transcription [133]. Numerous diverse etiologies have been developed and tested with this type of vaccination. Vaccination with both the Oxford-AstraZeneca as well as Pfizer-BioNTech vaccines, i.e. a mix and match COVID-19 vaccine approach, induces an effective immune response against the SARS-CoV-2 virus [134]. There is much optimism regarding nucleic acid-based vaccines, which show promise to become well-established and widely used in healthcare in the future. It would be fascinating to see if intranasal delivery of mRNA vaccines can enhance TRM cells and lung safety. Self-replicating mRNA vaccines could also boost protective T-cell immunity. Such composition and delivery route changes can also be used to optimize vaccines based on immune status and age $[50,66]$. SARS-CoV-2 annihilation from the community may be difficult due to reservoirs in unvaccinated individuals and/or other animal species. Promising vaccine dosage forms the variant $S$ sequences, and supplemental SARS-CoV-2 peptides could be developed, and yearly or semi-annual SARS-CoV-2 vaccines for persistent strains and/or seasonal variants could be administered. Furthermore, the safety and tolerability profile of these new technologies in provoking proinflammatory innate immune responses, as well as how the doses of these elements play a role, must be clearly explained [77]. Greater knowledge of the circumstances leading up to antigen expression, innate activation and adaptive responses may enable the development of a portfolio of nucleic acid-based vaccine and delivery systems with distinct properties.

The next five years will be critical for the field of Nucleic acid-based vaccines, with findings from many clinical studies offering a deeper picture of the technology's true 
possibilities as well as perspectives into the benefits and drawbacks of the numerous technologies and delivery systems under development.

\section{Conclusions}

Vaccines are sometimes referred to as one of the most important public health interventions in modern history, owing to their significant impact on global morbidity and mortality. Vaccine development typically takes 10-25 years, and research and analysis expenses can easily reach billions of dollars. So, in light of the COVID-19 pandemic, the inevitable inquiry is: How were the presently available vaccinations developed so quickly? In terms of development and production, it is obvious that nucleic acid-based vaccines represent a technology platform for novel urgent vaccines. There are over 60 such DNA and mRNA-based vaccine candidates under development. Both of these classes of vaccines have drawbacks, such as safety, the necessity for an adjuvant and the requirement for refrigerated storage. Nucleic acid vaccines based on mRNA and DNA are increasing in popularity and are beginning to occupy the pre-clinical and clinical pipelines to address such deficiencies. In addition, a number of delivery methods are being explored to protect mRNA or DNA-based vaccines against degradation, and as such, RNA nanocomposites are being developed that should, in theory, confer resistance against degradation, increasing its immunogenic potential. The delivery mechanism needs to be adequate and delivered to antigen-presenting cells in endosomes, then escape into the cytoplasm and protein production and the stimulation of adaptive immunity. In a very short time, nucleic acid-based vaccines have been produced and tested in human clinical trials with great outcomes thus far. Advancement in the formulation technology helps in the stabilization of the mRNA with a simple and robust manufacturing process. Nucleic acid vaccines provide similar protection to that of conventional vaccines without having to risk the serious consequences. As it is designed in the lab, the manufacturing process is comparatively easy and robust than conventional vaccines. Out of 22 EUA vaccine candidates, three are based on an mRNA platform, while one is based on a DNA platform that defines the ultimate success of this platform. To meet the global demand, a significant global collaboration between vaccine production and supply, funding bodies, legislators and federal governments is critical. In the next few years, we await to determine if these vaccines confer safety and protection long-term and whether this mode of vaccine formulation can be used for a number of other current and emerging diseases.

Author Contributions: V.P.C. involved in conceptualization, design, writing and editing of the article. J.B. and M.K.H. involved in the writing of the manuscript. V.A. and V.P.C. critically revised the manuscript. All authors have read and agreed to the published version of the manuscript.

Funding: This research received no external funding.

Acknowledgments: V.P. is thankful to the L M College of Pharmacy, Ahmedabad, India, for providing necessary support in carrying out the literature search. V.A would like to thank the Greek Orthodox Archdiocese of Australia, the Thelma and Paul Constantinou Foundation, the Pappas family and donors to the VU vaccine appeal, whose generous philanthropic support made this paper possible. V.A and M.K.H would also like to thank the Immunology and Translational Research Group, Institute for Health and Sport, Victoria University, for their significant contribution. M.K.H was supported by the Victoria University Postgraduate Scholarship and the Vice-Chancellor's top-up Scholarship Award. All figures in the manuscript were created using Biorender.com (Last accessed on 29 July 2021).

Conflicts of Interest: The authors declare no conflict of interest.

\section{References}

1. Dai, L.; Gao, G.F. Viral targets for vaccines against COVID-19. Nat. Rev. Immunol. 2020, 21, 73-82. [CrossRef]

2. Elwood, J.M. Smallpox and its eradication. J. Epidemiol. Community Health 1989, 43, 92. [CrossRef]

3. Nimmanapalli, R.; Gupta, V. Vaccines the tugboat for prevention-based animal production. Adv. Vet. Poult. Fish. 2019, 469-504. [CrossRef] 
4. Plotkin, S. History of vaccination. Proc. Natl. Acad. Sci. USA 2014, 111, 12283-12287. [CrossRef]

5. Kaur, S.P.; Gupta, V. COVID-19 Vaccine: A comprehensive status report. Virus Res. 2020, 288, 198114. [CrossRef]

6. World Health Organization. WHO SAGE Roadmap for Prioritizing Uses of COVID-19 Vaccines in the Context Of Limited Supply. Available online: https://www.who.int/publications/m/item/who-sage-roadmap-for-prioritizing-uses-of-covid-19-vaccinesin-the-context-of-limited-supply (accessed on 18 October 2021).

7. Al-Qahtani, A.A. Severe Acute Respiratory Syndrome Coronavirus 2 (SARS-CoV-2): Emergence, history, basic and clinical aspects. Saudi J. Biol. Sci. 2020, 27, 2531-2538. [CrossRef]

8. Chavda, V.P.; Apostolopoulos, V. Mucormycosis-An opportunistic infection in the aged immunocompromised individual: A reason for concern in COVID-19. Maturitas 2021. [CrossRef] [PubMed]

9. Sohrabi, C.; Alsafi, Z.; O’Neill, N.; Khan, M.; Kerwan, A.; Al-Jabir, A.; Iosifidis, C.; Agha, R. World Health Organization declares global emergency: A review of the 2019 novel coronavirus (COVID-19). Int. J. Surg. 2020, 76, 71-76. [CrossRef]

10. National Geographic. Moderna's mRNA Vaccine Reaches Its Final Phase. Here's How It Works. Available online: https://www. nationalgeographic.com/science/2020/05/moderna-coronavirus-vaccine-how-it-works-cvd/ (accessed on 18 October 2021).

11. World Heath Organization. The COVID-19 Vaccine Tracker and Landscape Compiles Detailed Information of Each COVID19 Vaccine Candidate in Development by Closely Monitoring Their Progress through the Pipeline. Available online: https: //www.who.int/publications/m/item/draft-landscape-of-covid-19-candidate-vaccines (accessed on 18 October 2021).

12. Zimmer, C.; Corum, J.; Wee, S. Coronavirus Vaccine Tracker. 2021. Available online: https://www.nytimes.com/interactive/2020 / science/coronavirus-vaccine-tracker.html (accessed on 18 October 2021).

13. McGill COVID19 Vaccine Tracker Team. COVID-19 Vaccine Tracker. 2021. Available online: https://covid19.trackvaccines.org/ vaccines/ (accessed on 11 May 2021).

14. World Health Organization. The Latest on the COVID-19 Global Situation \& Vaccine Development. Available online: https:/ / www.who.int/docs/default-source/coronaviruse/risk-comms-updates/update45-vaccines-developement.pdf? sfvrsn=13098bfc_5 (accessed on 18 October 2021).

15. Singh, T.U.; Parida, S.; Lingaraju, M.C.; Kesavan, M.; Kumar, D.; Singh, R.K. Drug repurposing approach to fight COVID-19. Pharmacol. Rep. 2020, 72, 1479-1508. [CrossRef]

16. Zhu, N.; Zhang, D.; Wang, W.; Li, X.; Yang, B.; Song, J.; Zhao, X.; Huang, B.; Shi, W.; Lu, R.; et al. A Novel Coronavirus from Patients with Pneumonia in China, 2019. N. Engl. J. Med. 2020, 382, 727-733. [CrossRef]

17. Restifo, N.P.; Ying, H.; Hwang, L.; Leitner, W. The promise of nucleic acid vaccines. Gene Ther. 2000, 7, 89-92. [CrossRef]

18. Mittal, K.A.; Manjunath, R.K.; Ranjan, S.; Kaushik, S.; Kumar, V. COVID-19 pandemic: Insights into structure, function, and hACE2 receptor recognition by SARS-CoV-2. PLoS Pathog. 2020, 16, e1008762. [CrossRef]

19. Huang, Y.; Yang, C.; Xu, X.-F.; Xu, W.; Liu, S.-W. Structural and functional properties of SARS-CoV-2 spike protein: Potential antivirus drug development for COVID-19. Acta Pharmacol. Sin. 2020, 41, 1141-1149. [CrossRef]

20. Wang, C.; Liu, Z.; Chen, Z.; Huang, X.; Xu, M.; He, T.; Zhang, Z. The establishment of reference sequence for SARS-CoV-2 and variation analysis. J. Med. Virol. 2020, 92, 667-674. [CrossRef] [PubMed]

21. Wu, A.; Peng, Y.; Huang, B.; Ding, X.; Wang, X.; Niu, P.; Meng, J.; Zhu, Z.; Zhang, Z.; Wang, J.; et al. Genome Composition and Divergence of the Novel Coronavirus (2019-nCoV) Originating in China. Cell Host Microbe 2020, 27, 325-328. [CrossRef]

22. Chan, J.F.-W.; Kok, K.-H.; Zhu, Z.; Chu, H.; To, K.K.-W.; Yuan, S.; Yuen, K.-Y. Genomic characterization of the 2019 novel human-pathogenic coronavirus isolated from a patient with atypical pneumonia after visiting Wuhan. Emerg. Microbes Infect. 2020, 9, 221-236. [CrossRef] [PubMed]

23. Satarker, S.; Nampoothiri, M. Structural Proteins in Severe Acute Respiratory Syndrome Coronavirus-2. Arch. Med. Res. 2020, 51, 482-491. [CrossRef]

24. Schoeman, D.; Fielding, B.C. Coronavirus envelope protein: Current knowledge. Virol. J. 2019, 16, 1-22. [CrossRef]

25. Siu, Y.L.; Teoh, K.T.; Lo, J.; Chan, C.M.; Kien, F.; Escriou, N.; Tsao, S.W.; Nicholls, J.M.; Altmeyer, R.; Peiris, J.S.M.; et al. The M, E, and N Structural Proteins of the Severe Acute Respiratory Syndrome Coronavirus Are Required for Efficient Assembly, Trafficking, and Release of Virus-Like Particles. J. Virol. 2008, 82, 11318-11330. [CrossRef]

26. Nieto-Torres, J.L.; DeDiego, M.L.; Álvarez, E.; Jiménez-Guardeño, J.M.; Regla-Nava, J.A.; Llorente, M.; Kremer, L.; Shuo, S.; Enjuanes, L. Subcellular location and topology of severe acute respiratory syndrome coronavirus envelope protein. Virology 2011, 415, 69-82. [CrossRef]

27. Voss, D.; Kern, A.; Traggiai, E.; Eickmann, M.; Stadler, K.; Lanzavecchia, A.; Becker, S. Characterization of severe acute respiratory syndrome coronavirus membrane protein. FEBS Lett. 2006, 580, 968-973. [CrossRef]

28. Huang, C.; Wang, Y.; Li, X.; Ren, L.; Zhao, J.; Hu, Y.; Zhang, L.; Fan, G.; Xu, J.; Gu, X.; et al. Clinical features of patients infected with 2019 novel coronavirus in Wuhan, China. Lancet 2020, 395, 497-506. [CrossRef]

29. Li, G.; Fan, Y.; Lai, Y.; Han, T.; Li, Z.; Zhou, P.; Pan, P.; Wang, W.; Hu, D.; Liu, X.; et al. Coronavirus infections and immune responses. J. Med. Virol. 2020, 92, 424-432. [CrossRef] [PubMed]

30. Baruah, V.; Bose, S. Immunoinformatics-aided identification of T cell and B cell epitopes in the surface glycoprotein of 2019-nCoV. J. Med. Virol. 2020, 92, 495-500. [CrossRef] [PubMed]

31. Yang, L.; Liu, S.; Liu, J.; Zhang, Z.; Wan, X.; Huang, B.; Chen, Y.; Zhang, Y. COVID-19: Immunopathogenesis and Immunotherapeutics. Signal Transduct. Target. Ther. 2020, 5, 1-8. [CrossRef] [PubMed] 
32. Li, W.; Moore, M.J.; Vasilieva, N.; Sui, J.; Wong, S.K.; Berne, M.A.; Somasundaran, M.; Sullivan, J.L.; Luzuriaga, K.; Greenough, T.C.; et al. Angiotensin-converting enzyme 2 is a functional receptor for the SARS coronavirus. Nature 2003, 426, 450-454. [CrossRef] [PubMed]

33. Chavda, V.; Feehan, J.; Apostolopoulos, V. A Veterinary Vaccine for SARS-CoV-2: The First COVID-19 Vaccine for Animals. Vaccines 2021, 9, 631. [CrossRef] [PubMed]

34. Chavda, V.P.; Vora, L.K.; Vihol, D.R. COVAX-19 ${ }^{\circledR}$ Vaccine: Completely blocks virus transmission to non-immune individuals. Clin. Complement. Med. Pharmacol. 2021, 1, 100004. [CrossRef]

35. Moon, C. Fighting COVID-19 exhausts T cells. Nat. Rev. Immunol. 2020, 20, 277. [CrossRef]

36. Tan, L.; Wang, Q.; Zhang, D.; Ding, J.; Huang, Q.; Tang, Y.-Q.; Wang, Q.; Miao, H. Lymphopenia predicts disease severity of COVID-19: A descriptive and predictive study. Signal Transduct. Target. Ther. 2020, 5, 1-3. [CrossRef]

37. Liu, Y.; Sun, W.; Li, J.; Chen, L.; Wang, Y.; Zhang, L.; Yu, L. Clinical features and progression of acute respiratory distress syndrome in coronavirus disease 2019. MedRxiv 2020. [CrossRef]

38. Smith, C.K.; Trinchieri, G. The interplay between neutrophils and microbiota in cancer. J. Leukoc. Biol. 2018, 104, 701-715. [CrossRef]

39. Deshmukh, H.S.; Liu, Y.; Menkiti, O.R.; Mei, J.; Dai, N.; O’Leary, C.E.; Oliver, P.M.; Kolls, J.K.; Weiser, J.N.; Worthen, G.S. The microbiota regulates neutrophil homeostasis and host resistance to Escherichia coli K1 sepsis in neonatal mice. Nat. Med. 2014, 20, 524-530. [CrossRef]

40. Zhou, Y.; Fu, B.; Zheng, X.; Wang, D.; Zhao, C.; Qi, Y.; Sun, R.; Tian, Z.; Xu, X.; Wei, H. Aberrant pathogenic GM-CSF+ T cells and inflammatory CD14+CD16+ monocytes in severe pulmonary syndrome patients of a new coronavirus. bioRxiv 2020. [CrossRef]

41. Wen, W.; Su, W.; Tang, H.; Le, W.; Zhang, X.; Zheng, Y.; Liu, X.; Xie, L.; Li, J.; Ye, J.; et al. Immune cell profiling of COVID-19 patients in the recovery stage by single-cell sequencing. Cell Discov. 2020, 6, 1-18. [CrossRef]

42. Wu, D.; Yang, X.O. TH17 responses in cytokine storm of COVID-19: An emerging target of JAK2 inhibitor Fedratinib. J. Microbiol. Immunol. Infect. 2020, 53, 368-370. [CrossRef] [PubMed]

43. Xu, Z.; Shi, L.; Wang, Y.; Zhang, J.; Huang, L.; Zhang, C.; Liu, S.; Zhao, P.; Liu, H.; Zhu, L.; et al. Pathological findings of COVID-19 associated with acute respiratory distress syndrome. Lancet Respir. Med. 2020, 8, 420-422. [CrossRef]

44. Diao, B.; Wang, C.; Tan, Y.; Chen, X.; Liu, Y.; Ning, L.; Chen, L.; Li, M.; Liu, Y.; Wang, G.; et al. Reduction and Functional Exhaustion of T Cells in Patients with Coronavirus Disease 2019 (COVID-19). Front. Immunol. 2020, 11, 827. [CrossRef]

45. Yip, M.S.; Leung, H.L.; Li, P.H.; Cheung, C.Y.; Dutry, I.; Li, D.; Daëron, M.; Bruzzone, R.; Peiris, J.S.M.; Jaume, M. Antibodydependent enhancement of SARS coronavirus infection and its role in the pathogenesis of SARS. Hong Kong Med. J. 2016, 22, 25-31. [CrossRef]

46. Katzelnick, L.C.; Gresh, L.; Halloran, M.E.; Mercado, J.C.; Kuan, G.; Gordon, A.; Balmaseda, A.; Harris, E. Antibody-dependent enhancement of severe dengue disease in humans. Science 2017, 358, 929-932. [CrossRef]

47. Roncati, L.; Nasillo, V.; Lusenti, B.; Riva, G. Signals of Th2 immune response from COVID-19 patients requiring intensive care. Ann. Hematol. 2020, 99, 1419-1420. [CrossRef]

48. Malik, J.A.; Mulla, A.H.; Farooqi, T.; Pottoo, F.H.; Anwar, S.; Rengasamy, K.R. Targets and strategies for vaccine development against SARS-CoV-2. Biomed. Pharmacother. 2021, 137, 111254. [CrossRef] [PubMed]

49. Pollard, A.J.; Bijker, E.M. A guide to vaccinology: From basic principles to new developments. Nat. Rev. Immunol. 2020, 21, 83-100. [CrossRef] [PubMed]

50. Chavda, V.P.; Vora, L.K.; Pandya, A.K.; Patravale, V.B. Intranasal vaccines for SARS-CoV-2: From challenges to potential in COVID-19 management. Drug Discov. Today 2021. [CrossRef] [PubMed]

51. Van Riel, D.; De Wit, E. Next-generation vaccine platforms for COVID-19. Nat. Mater. 2020, 19, 810-812. [CrossRef] [PubMed]

52. Wu, S. Progress and Concept for COVID-19 Vaccine Development. Biotechnol. J. 2020, 15, e2000147. [CrossRef] [PubMed]

53. Mehta, M.; Shyh, G.I. A Review of Remdesivir for COVID-19: Data to Date. Cardiol. Rev. 2020, 28, 332-334. [CrossRef]

54. Singh, A.K.; Singh, A.; Singh, R.; Misra, A. Remdesivir in COVID-19: A critical review of pharmacology, pre-clinical and clinical studies. Diabetes Metab. Syndr. Clin. Res. Rev. 2020, 14, 641-648. [CrossRef] [PubMed]

55. Frediansyah, A.; Nainu, F.; Dhama, K.; Mudatsir, M.; Harapan, H. Remdesivir and its antiviral activity against COVID-19: A systematic review. Clin. Epidemiol. Glob. Health 2020, 9, 123-127. [CrossRef]

56. Vasou, A.; Sultanoglu, N.; Goodbourn, S.; Randall, R.; Kostrikis, L.G. Targeting Pattern Recognition Receptors (PRR) for Vaccine Adjuvantation: From Synthetic PRR Agonists to the Potential of Defective Interfering Particles of Viruses. Viruses $2017,9,186$. [CrossRef]

57. de Queiroz, N.M.G.; Marinho, F.V.; Chagas, M.A.; Leite, L.C.; Homan, E.J.; de Magalhães, M.T.; Oliveira, S.C. Vaccines for COVID-19: Perspectives from nucleic acid vaccines to BCG as delivery vector system. Microbes Infect. 2020, 22, 515-524. [CrossRef]

58. Speiser, D.E.; Bachmann, M.F. COVID-19: Mechanisms of Vaccination and Immunity. Vaccines 2020, 8, 404. [CrossRef]

59. Redding, L.; Weiner, D.B. DNA vaccines in veterinary use. Expert Rev. Vaccines 2009, 8, 1251-1276. [CrossRef]

60. Piyush, R.; Rajarshi, K.; Chatterjee, A.; Khan, R.; Ray, S. Nucleic acid-based therapy for coronavirus disease 2019. Heliyon 2020, 6, e05007. [CrossRef]

61. Vogel, F.R.; Sarver, N. Nucleic acid vaccines. Clin. Microbiol. Rev. 1995, 8, 406-410. [CrossRef]

62. Liu, M.A. A Comparison of Plasmid DNA and mRNA as Vaccine Technologies. Vaccines 2019, 7, 37. [CrossRef] [PubMed] 
63. Rauch, S.; Jasny, E.; Schmidt, K.E.; Petsch, B. New Vaccine Technologies to Combat Outbreak Situations. Front. Immunol. 2018, 9, 1963. [CrossRef]

64. Risitano, A.M.; Mastellos, D.C.; Huber-Lang, M.; Yancopoulou, D.; Garlanda, C.; Ciceri, F.; Lambris, J.D. Complement as a target in COVID-19? Nat. Rev. Immunol. 2020, 20, 343-344. [CrossRef] [PubMed]

65. Xu, S.; Yang, K.; Li, R.; Zhang, L. mRNA Vaccine Era-Mechanisms, Drug Platform and Clinical Prospection. Int. J. Mol. Sci. 2020, 21, 6582. [CrossRef] [PubMed]

66. Teijaro, J.R.; Farber, D.L. COVID-19 vaccines: Modes of immune activation and future challenges. Nat. Rev. Immunol. 2021, 21, 195-197. [CrossRef]

67. Heine, A.; Juranek, S.; Brossart, P. Clinical and immunological effects of mRNA vaccines in malignant diseases. Mol. Cancer 2021, 20,1-20. [CrossRef]

68. Kyriakidis, N.C.; López-Cortés, A.; González, E.V.; Grimaldos, A.B.; Prado, E.O. SARS-CoV-2 vaccines strategies: A comprehensive review of phase 3 candidates. npj Vaccines 2021, 6, 1-17. [CrossRef]

69. McNamara, M.A.; Nair, S.K.; Holl, E.K. RNA-Based Vaccines in Cancer Immunotherapy. J. Immunol. Res. 2015, 2015, 1-9. [CrossRef] [PubMed]

70. Bettini, E.; Locci, M. SARS-CoV-2 mRNA Vaccines: Immunological Mechanism and Beyond. Vaccines 2021, 9, 147. [CrossRef] [PubMed]

71. Widge, A.T.; Rouphael, N.G.; Jackson, L.A.; Anderson, E.J.; Roberts, P.C.; Makhene, M.; Chappell, J.D.; Denison, M.R.; Stevens, L.J.; Pruijssers, A.J.; et al. Durability of Responses after SARS-CoV-2 mRNA-1273 Vaccination. N. Engl. J. Med. 2021, 384, 80-82. [CrossRef] [PubMed]

72. Paik, D.H.; Farber, D.L. Anti-viral protective capacity of tissue resident memory T cells. Curr. Opin. Virol. 2020, 46, 20-26. [CrossRef] [PubMed]

73. Polack, F.P.; Thomas, S.J.; Kitchin, N.; Absalon, J.; Gurtman, A.; Lockhart, S.; Perez, J.L.; Marc, G.P.; Moreira, E.D.; Zerbini, C.; et al Safety and Efficacy of the BNT162b2 mRNA Covid-19 Vaccine. N. Engl. J. Med. 2020, 383, 2603-2615. [CrossRef]

74. Lange, A.; Borowik, A.; Bocheńska, J.; Rossowska, J.; Jaskuła, E. Immune Response to COVID-19 mRNA Vaccine-A Pilot Study. Vaccines 2021, 9, 488. [CrossRef]

75. Dey, A.; Rajanathan, T.C.; Chandra, H.; Pericherla, H.P.; Kumar, S.; Choonia, H.S.; Bajpai, M.; Singh, A.K.; Sinha, A.; Saini, G.; et al. Immunogenic potential of DNA vaccine candidate, ZyCoV-D against SARS-CoV-2 in animal models. Vaccine 2021, 39, 4108-4116. [CrossRef]

76. Jackson, N.A.C.; Kester, K.E.; Casimiro, D.; Gurunathan, S.; DeRosa, F. The promise of mRNA vaccines: A biotech and industrial perspective. npj Vaccines 2020, 5, 1-6. [CrossRef]

77. Maruggi, G.; Zhang, C.; Li, J.; Ulmer, J.B.; Yu, D. mRNA as a Transformative Technology for Vaccine Development to Control Infectious Diseases. Mol. Ther. 2019, 27, 757-772. [CrossRef]

78. Pardi, N.; Hogan, M.; Porter, F.W.; Weissman, D. mRNA vaccines-A new era in vaccinology. Nat. Rev. Drug Discov. 2018, 17, 261-279. [CrossRef] [PubMed]

79. Huang, Q.; Zeng, J.; Yan, J. COVID-19 mRNA vaccines. J. Genet. Genom. 2021, 48, 107-114. [CrossRef] [PubMed]

80. Guan, S.; Rosenecker, J. Nanotechnologies in delivery of mRNA therapeutics using nonviral vector-based delivery systems. Gene Ther. 2017, 24, 133-143. [CrossRef] [PubMed]

81. Park, K.S.; Sun, X.; Aikins, M.E.; Moon, J.J. Non-viral COVID-19 vaccine delivery systems. Adv. Drug Deliv. Rev. 2020, 169, 137-151. [CrossRef] [PubMed]

82. Dolgin, E. COVID-19 vaccines poised for launch, but impact on pandemic unclear. Nat. Biotechnol. 2020. [CrossRef] [PubMed]

83. Rahman, G. RNA Covid-19 Vaccines Will Not Change Your DNA. 2021. Available online: https://fullfact.org/online/rnavaccine-covid/ (accessed on 2 June 2021).

84. Kauffman, K.J.; Webber, M.; Anderson, D.G. Materials for non-viral intracellular delivery of messenger RNA therapeutics. J. Control. Release 2016, 240, 227-234. [CrossRef] [PubMed]

85. Karikó, K.; Muramatsu, H.; Welsh, F.A.; Ludwig, J.; Kato, H.; Akira, S.; Weissman, D. Incorporation of Pseudouridine Into mRNA Yields Superior Nonimmunogenic Vector with Increased Translational Capacity and Biological Stability. Mol. Ther. 2008, 16, 1833-1840. [CrossRef] [PubMed]

86. Karikó, K.; Muramatsu, H.; Ludwig, J.; Weissman, D. Generating the optimal mRNA for therapy: HPLC purification eliminates immune activation and improves translation of nucleoside-modified, protein-encoding mRNA. Nucleic Acids Res. 2011, 39 , e142. [CrossRef]

87. Thess, A.; Grund, S.; Mui, B.L.; Hope, M.J.; Baumhof, P.; Fotin-Mleczek, M.; Schlake, T. Sequence-engineered mRNA without Chemical Nucleoside Modifications Enables an Effective Protein Therapy in Large Animals. Mol. Ther. 2015, 23, 1456-1464. [CrossRef] [PubMed]

88. Baden, L.R.; El Sahly, H.M.; Essink, B.; Kotloff, K.; Frey, S.; Novak, R.; Diemert, D.; Spector, S.A.; Rouphael, N.; Creech, C.B.; et al. Efficacy and Safety of the mRNA-1273 SARS-CoV-2 Vaccine. N. Engl. J. Med. 2021, 384, 403-416. [CrossRef]

89. Tsui, N.B.; Ng, E.K.; Lo, Y.D. Stability of Endogenous and Added RNA in Blood Specimens, Serum, and Plasma. Clin. Chem. 2002, 48, 1647-1653. [CrossRef] [PubMed]

90. Kallen, K.-J.; Theß, A. A development that may evolve into a revolution in medicine: mRNA as the basis for novel, nucleotidebased vaccines and drugs. Ther. Adv. Vaccines 2013, 2, 10-31. [CrossRef] [PubMed] 
91. Kis, Z.; Shattock, R.; Shah, N.; Kontoravdi, C. Emerging Technologies for Low-Cost, Rapid Vaccine Manufacture. Biotechnol. J. 2018, 14, e1800376. [CrossRef] [PubMed]

92. Jackson, L.A.; Anderson, E.J.; Rouphael, N.G.; Roberts, P.C.; Makhene, M.; Coler, R.N.; McCullough, M.P.; Chappell, J.D.; Denison, M.R.; Stevens, L.J.; et al. An mRNA Vaccine against SARS-CoV-2_Preliminary Report. N. Engl. J. Med. 2020, 383. [CrossRef]

93. Liu, L.; Wei, Q.; Lin, Q.; Fang, J.; Wang, H.; Kwok, H.; Tang, H.; Nishiura, K.; Peng, J.; Tan, Z.; et al. Anti-spike IgG causes severe acute lung injury by skewing macrophage responses during acute SARS-CoV infection. JCI Insight 2019, 4. [CrossRef] [PubMed]

94. Anderson, E.J.; Rouphael, N.G.; Widge, A.T.; Jackson, L.A.; Roberts, P.C.; Makhene, M.; Chappell, J.D.; Denison, M.R.; Stevens, L.J.; Pruijssers, A.J.; et al. Safety and Immunogenicity of SARS-CoV-2 mRNA-1273 Vaccine in Older Adults. N. Engl. J. Med. 2020, 383, 2427-2438. [CrossRef]

95. U.S. Food and Drug Administration. Moderna COVID-19 Vaccine. Available online: https://www.fda.gov/emergencypreparedness-and-response/coronavirus-disease-2019-covid-19/moderna-covid-19-vaccine (accessed on 27 September 2021).

96. Vogel, A.B.; Kanevsky, I.; Che, Y.; Swanson, K.A.; Muik, A.; Vormehr, M.; Kranz, L.M.; Walzer, K.C.; Hein, S.; Güler, A.; et al. A prefusion SARS-CoV-2 spike RNA vaccine is highly immunogenic and prevents lung infection in non-human primates. BioRxiv 2020. [CrossRef]

97. Sahin, U.; Muik, A.; Vogler, I.; Derhovanessian, E.; Kranz, L.M.; Vormehr, M.; Quandt, J.; Bidmon, N.; Ulges, A.; Baum, A.; et al. BNT162b2 induces SARS-CoV-2-neutralising antibodies and T cells in humans. medRxiv 2020. [CrossRef]

98. USFDA. FDA Approves First COVID-19 Vaccine. 2021. Available online: https://www.fda.gov/news-events/pressannouncements / fda-approves-first-covid-19-vaccine (accessed on 27 September 2021).

99. Reautschnig, P.; Vogel, P.; Stafforst, T. The notorious R.N.A. in the spotlight-Drug or target for the treatment of disease. RNA Biol. 2016, 14, 651-668. [CrossRef]

100. Stitz, L.; Vogel, A.; Schnee, M.; Voss, D.; Rauch, S.; Mutzke, T.; Ketterer, T.; Kramps, T.; Petsch, B. A thermostable messenger RNA based vaccine against rabies. PLOS Negl. Trop. Dis. 2017, 11, e0006108. [CrossRef] [PubMed]

101. Apostolopoulos, V.; Plebanski, M. The evolution of DNA vaccines. Curr. Opin. Mol. Ther. 2000, 2, 441-447. [PubMed]

102. Chavda, V.P.; Pandya, R.; Apostolopoulos, V. DNA vaccines for SARS-CoV-2: Towards third generation vaccination era. Expert Rev. Vaccines 2021. [CrossRef]

103. Singh, S. India Gives Emergency Approval for World's First COVID-19 DNA Vaccine. Available online: https://www.reuters. com/business/healthcare-pharmaceuticals/india-approves-zydus-cadilas-covid-19-vaccine-emergency-use-2021-08-20/ (accessed on 21 August 2021).

104. Cadila Healthcare Ltd. Zydus Cadila Receives Approvals from the DCGI to Start Phase III Clinical Trial of ZyCoV-D-Fully Indigenously Developed Vaccine. 2021. Available online: https://zyduscadila.com/public/pdf/pressrelease/Zydus_Cadila_ receives_approvals_from_the_DCGI_to_start_Phase_III_Clinical_Trial_of_ZyCoV_D_fully_indigenously_developed_vaccine_ -3_1_2021.pdf (accessed on 1 June 2021).

105. Momin, T.; Kansagra, K.; Patel, H.; Sharma, S.; Sharma, B.; Patel, J.; Mittal, R.; Sanmukhani, J.; Maithal, K.; Dey, A.; et al. Safety and Immunogenicity of a DNA SARS-CoV-2 vaccine (ZyCoV-D): Results of an open-label, non-randomized phase I part of phase I/II clinical study by intradermal route in healthy subjects in India. EClinicalMedicine 2021, 38, 101020. [CrossRef]

106. Modjarrad, K.; Roberts, C.C.; Mills, K.T.; Castellano, A.R.; Paolino, K.; Muthumani, K.; Reuschel, E.L.; Robb, M.L.; Racine, T.; Oh, M.-D.; et al. Safety and immunogenicity of an anti-Middle East respiratory syndrome coronavirus DNA vaccine: A phase 1, open-label, single-arm, dose-escalation trial. Lancet Infect. Dis. 2019, 19, 1013-1022. [CrossRef]

107. Smith, T.R.F.; Patel, A.; Ramos, S.; Elwood, D.; Zhu, X.; Yan, J.; Gary, E.N.; Walker, S.N.; Schultheis, K.; Purwar, M.; et al. Immunogenicity of a DNA vaccine candidate for COVID-19. Nat. Commun. 2020, 11, 2601. [CrossRef] [PubMed]

108. Tebas, P.; Yang, S.; Boyer, J.D.; Reuschel, E.L.; Patel, A.; Christensen-Quick, A.; Andrade, V.M.; Morrow, M.P.; Kraynyak, K.; Agnes, J.; et al. Safety and immunogenicity of INO-4800 DNA vaccine against SARS-CoV-2: A preliminary report of an open-label, Phase 1 clinical trial. EClinicalMedicine 2020, 31, 100689. [CrossRef]

109. Schmeer, M.; Buchholz, T.; Schleef, M. Plasmid DNA Manufacturing for Indirect and Direct Clinical Applications. Hum. Gene Ther. 2017, 28, 856-861. [CrossRef]

110. Brocato, R.L.; Kwilas, S.A.; Josleyn, M.D.; Long, S.; Zeng, X.; Perley, C.C.; Principe, L.M.; Somerville, B.; Cohen, M.V.; Hooper, J.W. Small animal jet injection technique results in enhanced immunogenicity of hantavirus DNA vaccines. Vaccine 2021, 39, 1101-1110. [CrossRef]

111. Sokołowska, E.; Błachnio-Zabielska, A.U. A Critical Review of Electroporation as A Plasmid Delivery System in Mouse Skeletal Muscle. Int. J. Mol. Sci. 2019, 20, 2776. [CrossRef] [PubMed]

112. Liu, M.A. Immunologic Basis of Vaccine Vectors. Immunity 2010, 33, 504-515. [CrossRef] [PubMed]

113. Schlake, T.; Thess, A.; Thran, M.; Jordan, I. mRNA as novel technology for passive immunotherapy. Experientia 2018, 76, 301-328. [CrossRef]

114. Pardi, N.; Weissman, D. Nucleoside Modified mRNA Vaccines for Infectious Diseases. Methods Mol. Biol. 2016, 1499 , $109-121$. [CrossRef]

115. Lim, B.; Lee, K. Stability of the Osmoregulated Promoter-DerivedproPmRNA Is Posttranscriptionally Regulated by RNase III in Escherichia coli. J. Bacteriol. 2015, 197, 1297-1305. [CrossRef] [PubMed]

116. Zarghampoor, F.; Azarpira, N.; Khatami, S.R.; Behzad-Behbahani, A.; Foroughmand, A.M. Improved translation efficiency of therapeutic mRNA. Gene 2019, 707, 231-238. [CrossRef] 
117. Li, S.S.; Kochar, N.K.; Elizaga, M.; Hay, C.M.; Wilson, G.J.; Cohen, K.W.; De Rosa, S.C.; Xu, R.; Ota-Setlik, A.; Morris, D.; et al. DNA Priming Increases Frequency of T-Cell Responses to a Vesicular Stomatitis Virus HIV Vaccine with Specific Enhancement of CD8 + T-Cell Responses by Interleukin-12 Plasmid DNA. Clin. Vaccine Immunol. 2017, 24. [CrossRef]

118. Apostolopoulos, V.; Weiner, D.B. Development of more efficient and effective DNA vaccines. Expert Rev. Vaccines 2009, 8, 1133-1134. [CrossRef]

119. Silveira, M.M.; Moreira, G.M.S.G.; Mendonça, M. DNA vaccines against COVID-19: Perspectives and challenges. Life Sci. 2020, 267, 118919. [CrossRef]

120. Tang, C.-K.; Sheng, K.-C.; Apostolopoulos, V.; Pietersz, G.A. Protein/peptide and DNA vaccine delivery by targeting C-type lectin receptors. Expert Rev. Vaccines 2008, 7, 1005-1018. [CrossRef]

121. Chandler, M.; Johnson, M.B.; Panigaj, M.; Afonin, K.A. Innate immune responses triggered by nucleic acids inspire the design of immunomodulatory nucleic acid nanoparticles (NANPs). Curr. Opin. Biotechnol. 2019, 63, 8-15. [CrossRef]

122. Wadhwa, A.; Aljabbari, A.; Lokras, A.; Foged, C.; Thakur, A. Opportunities and Challenges in the Delivery of mRNA-Based Vaccines. Pharmaceutics 2020, 12, 102. [CrossRef] [PubMed]

123. Rosa, S.S.; Prazeres, D.M.; Azevedo, A.M.; Marques, M.P. mRNA vaccines manufacturing: Challenges and bottlenecks. Vaccine 2021, 39, 2190-2200. [CrossRef] [PubMed]

124. Anthony, D.P.S.; Sivakumar, K.; Venugopal, P.; Sriram, D.K.; George, M. Can mRNA Vaccines Turn the Tables During the COVID-19 Pandemic? Current Status and Challenges. Clin. Drug Investig. 2021, 41, 499-509. [CrossRef] [PubMed]

125. Hossain, K.; Hassanzadeganroudsari, M.; Feehan, J.; Apostolopoulos, V. COVID-19 Vaccines in the Pipeline, Are Antibodies Adequate? Vaccines 2021, 9, 241. [CrossRef] [PubMed]

126. Hossain, K.; Hassanzadeganroudsari, M.; Apostolopoulos, V. The emergence of new strains of SARS-CoV-2. What does it mean for COVID-19 vaccines? Expert Rev. Vaccines 2021, 20, 635-638. [CrossRef] [PubMed]

127. Turner, J.S.; O’Halloran, J.A.; Kalaidina, E.; Kim, W.; Schmitz, A.J.; Zhou, J.Q.; Lei, T.; Thapa, M.; Chen, R.E.; Case, J.B.; et al. SARS-CoV-2 mRNA vaccines induce persistent human germinal centre responses. Nature 2021, 596, 109-113. [CrossRef] [PubMed]

128. Hall, V.G.; Ferreira, V.H.; Ku, T.; Ierullo, M.; Majchrzak-Kita, B.; Chaparro, C.; Selzner, N.; Schiff, J.; McDonald, M.; Tomlinson, G.; et al. Randomized Trial of a Third Dose of mRNA-1273 Vaccine in Transplant Recipients. N. Engl. J. Med. 2021, 385, 1244-1246. [CrossRef] [PubMed]

129. Forni, G.; Mantovani, A. COVID-19 vaccines: Where we stand and challenges ahead. Cell Death Differ. 2021, $28,626-639$. [CrossRef] [PubMed]

130. Calina, D.; Docea, A.O.; Petrakis, D.; Egorov, A.M.; Ishmukhametov, A.A.; Gabibov, A.G.; Shtilman, M.I.; Kostoff, R.; Carvalho, F.; Vinceti, M.; et al. Towards effective COVID-19 vaccines: Updates, perspectives and challenges (Review). Int. J. Mol. Med. 2020, 46, 3-16. [CrossRef] [PubMed]

131. Freyn, A.W.; da Silva, J.R.; Rosado, V.C.; Bliss, C.M.; Pine, M.; Mui, B.L.; Tam, Y.K.; Madden, T.D.; Ferreira, L.C.D.S.; Weissman, D.; et al. A Multi-Targeting, Nucleoside-Modified mRNA Influenza Virus Vaccine Provides Broad Protection in Mice. Mol. Ther. 2020, 28, 1569-1584. [CrossRef] [PubMed]

132. Feldman, R.A.; Fuhr, R.; Smolenov, I.; Ribeiro, A.; Panther, L.; Watson, M.; Senn, J.J.; Smith, M.; Almarsson, Ö.; Pujar, H.S.; et al. mRNA vaccines against H10N8 and H7N9 influenza viruses of pandemic potential are immunogenic and well tolerated in healthy adults in phase 1 randomized clinical trials. Vaccine 2019, 37, 3326-3334. [CrossRef] [PubMed]

133. Ulmer, J.B.; Mansoura, M.K.; Geall, A.J. Vaccines 'on demand': Science fiction or a future reality. Expert Opin. Drug Discov. 2015, 10, 101-106. [CrossRef] [PubMed]

134. Callaway, E. Mix-and-match COVID vaccines trigger potent immune response. Nature 2021, 593, 491. [CrossRef] [PubMed] 